To the University of Wyoming:

The members of the Committee approve the thesis of Sara Carabajal presented on $5 / 4 / 2018$.

Randa Jabbour, Chairperson

Tim Collier, Outside Member

Andrew Kniss

APPROVED:

Jim Heitholt, Department Head, Plant Science.

Frank Galey, College Dean 
Carabajal, Sara C., Functional Diversity Of Interseeded Cover Crops And Their Effect On Carabid Activity-Density In Semi-Arid Climates, MS, Department of Plant Science, August, 2018.

Interseeding cover crops into standing annual crops can promote environmental benefits within agroecosystems. However, seeding method and cover crop diversity may influence biomass production and activity-density of ground beetles (Coleoptera: Carabidae). Carabids abundant in agroecosystems and their granivorous behavior can impact weeds and potentially crops. In a two-year study, six annual cover crop species- planted as either single species or mixtures- were interseeded into standing corn. The seed predation rate of Harpalus, a granivorous carabid, was estimated in a no-choice experiment using weed and crop seed species. Higher crop diversity did not correlate with biomass yield, but cover crop species did. Carabid activity-density was significantly higher later in the season, but was not influenced by diversity or species. Harpalus consumed crop seeds, but preferred weed seed. With further experimentation and analysis, these results can inform farmers in choosing the most effective seeding method and seed type for interseeded cover crop establishment. 


\section{FUNCTIONAL DIVERSITY OF INTERSEEDED COVER CROPS AND THEIR EFFECT ON CARABID ACTIVITY-DENSITY IN SEMI-ARID CLIMATES}

By

Sara Carabajal

A thesis submitted to the Department of Plant Sciences

and the University of Wyoming

in partial fulfillment of the requirements

for the degree of

MASTERS OF SCIENCE

in

AGRONOMY

Laramie, Wyoming

August, 2018 
COPYRIGHT PAGE

(C) 2018, Sara Carabajal 
Copyright page

.ii

Dedication page. Error! Bookmark not defined.

Acknowledgements ..Error! Bookmark not defined.

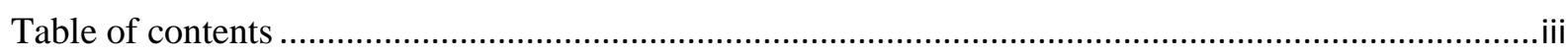

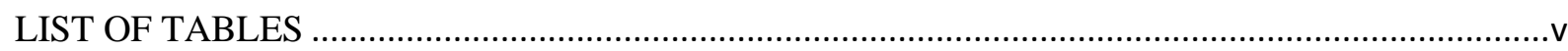

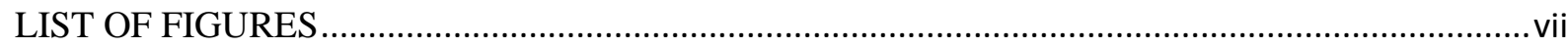

CHAPTER ONE: CARABID RESPONSE TO BROADCAST INTERSEEDING AND

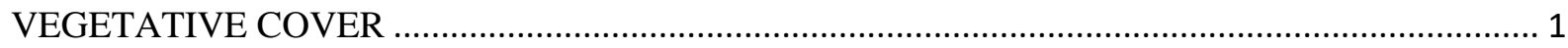

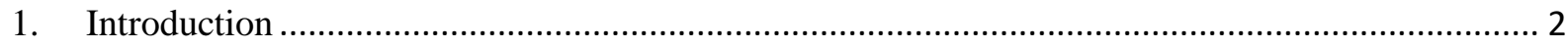

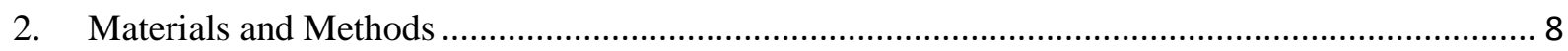

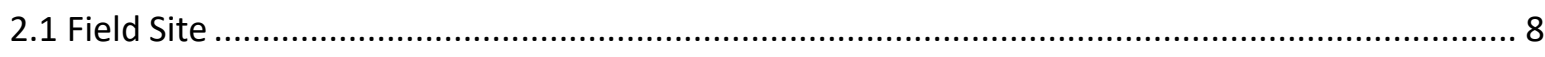

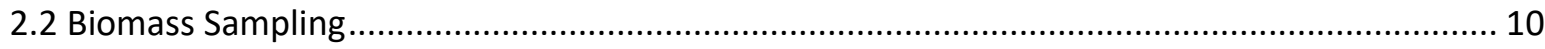

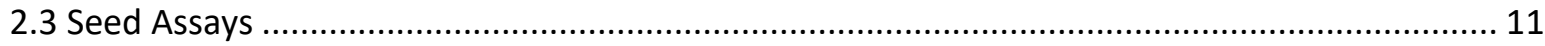

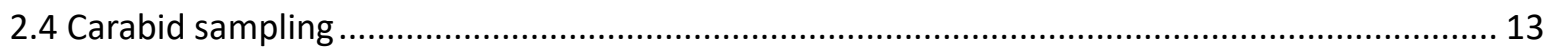

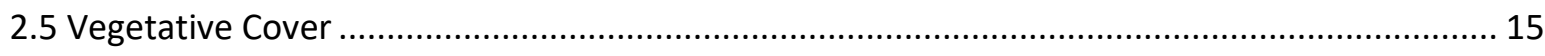

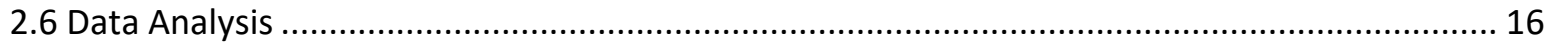

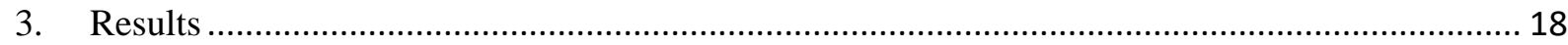

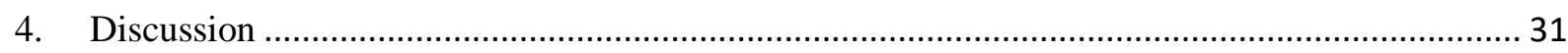

CHAPTER TWO: SEED PREDATION RATES OF HARPALUS ….......................................... 37

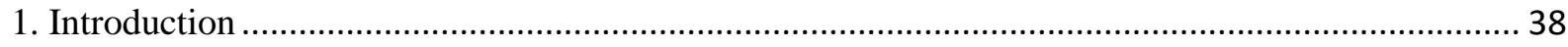

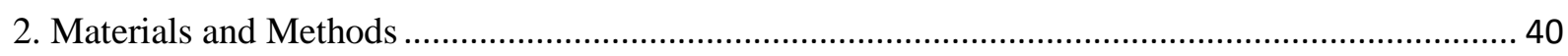

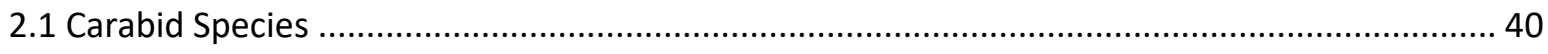

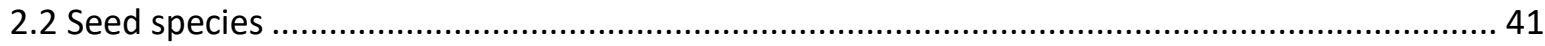

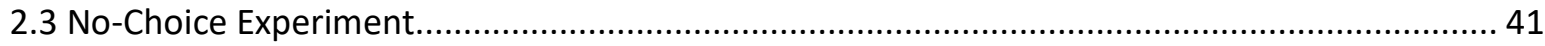

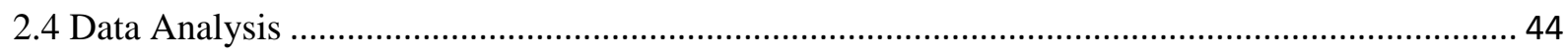

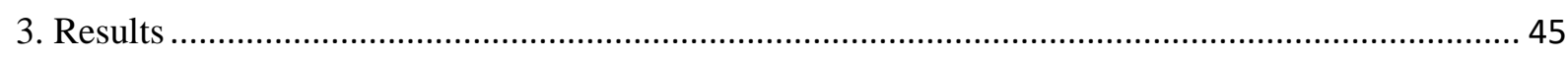

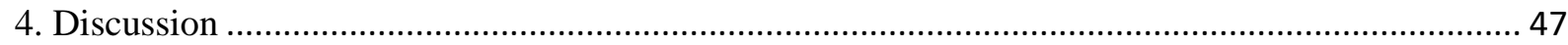

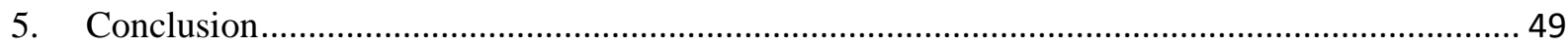




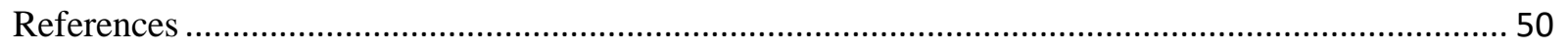

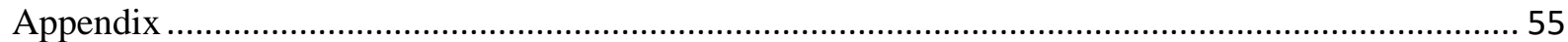




\section{LIST OF TABLES}

Table 1: Seeding treatments based on e-Organics seeding recommendations (White, et al., 2016)... 10

Table 2: Average total biomass production and standard deviation by cover crop treatment............ 21

Table 3: Average crop biomass and standard deviation by cover crop treatment ............................. 21

Table 4: Average biomass and percent composition contributed by species and functional groups

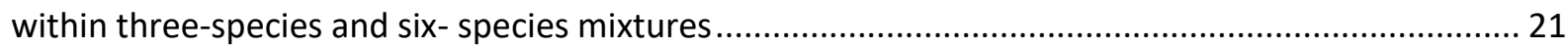

Table 5: weight in grams of 100 seeds for each seed species ....................................................... 41

Table 6: Average consumption and standard deviation (SD) for each seed species. Average

consumption is reported as percent consumed out of 50 seeds ................................................ 46

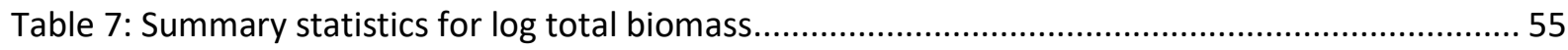

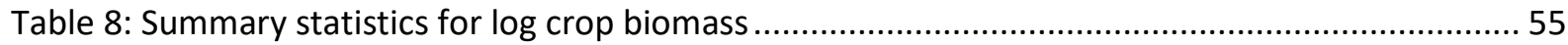

Table 9: Summary statistics for log weed biomass .......................................................................... 55

Table 10: Summary statistics for 2016 seed assay analysis ........................................................... 55

Table 11: Summary statistics for 2017 seed assay analysis. Repetitions increased from four to five in

2017.

55

Table 12: Summary statistics for 2016 average vegetative cover analysis.......................................56

Table 13: Average vegetative cover analysis for 2017. Analysis of Variance Table of type III with

Satterthwaite approximation for degrees of freedom. .............................................................. 56

Table 14: Pitfall summary for 2016. Analysis of Variance Table of type III with Satterthwaite

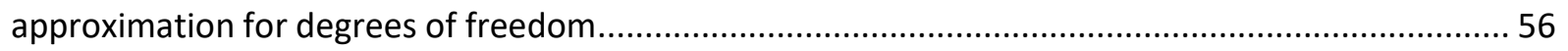


Table 15: Pitfall summary for 2017. Analysis of Variance Table of type III with Satterthwaite

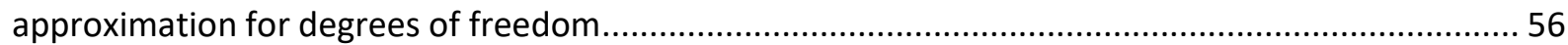




\section{LIST OF FIGURES}

Figure 1: Seed assays: A) open treatment, B) exclosure treatment.............................................. 13

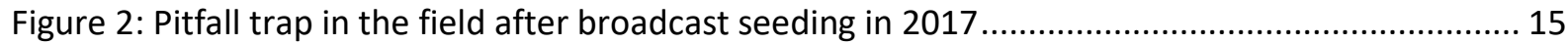

Figure 3: Pitfall trap in the field after seedling emergence in 2017............................................. 15

Figure 4: Total biomass (log transformed kg/ha) of seven interseeded cover crop treatments in 2016;

bold line represents the median value, boxes encompass $25^{\text {th }}$ to $75^{\text {th }}$ percentile, and vertical lines

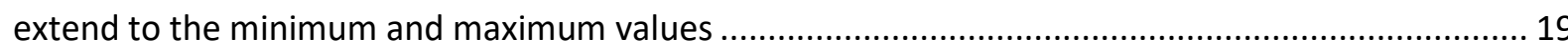

Figure 5: Cover crop biomass (log transformed kg/ha) of seven interseeded cover crop treatments in 2016; bold line represents the median value, boxes encompass $25^{\text {th }}$ to $75^{\text {th }}$ percentile, and vertical

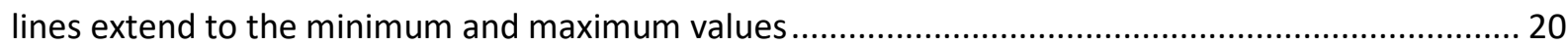

Figure 6: Weed biomass (log transformed kg/ha) of seven interseeded cover crop treatments in 2016; bold line represents the median value, boxes encompass $25^{\text {th }}$ to $75^{\text {th }}$ percentile, and vertical lines extend to the minimum and maximum values......

Figure 7: Removed seeds (out of 60 total seeds from seed assay) were measured for three treatments in 2016; bold line represents the median value, boxes encompass $25^{\text {th }}$ to $75^{\text {th }}$ percentile, and vertical lines extend to the minimum and maximum values 23

Figure 8: Removed seeds (out of 60 total seeds from seed assay) were measured for three treatments in 2017; bold line represents the median value, boxes encompass $25^{\text {th }}$ to $75^{\text {th }}$ percentile, and vertical lines extend to the minimum and maximum values 24

Figure 9: Carabid activity-density from pitfall traps on June 29 (during seeding) and July 2 (after seedling emergence) in 2016; bold line represents the median value, boxes encompass $25^{\text {th }}$ to $75^{\text {th }}$ percentile, and vertical lines extend to the minimum and maximum values 
Figure 10: Carabid activity-density from pitfall traps July 7, August 2, and August 24 in 2017; bold line represents the median value, boxes encompass $25^{\text {th }}$ to $75^{\text {th }}$ percentile, and vertical lines extend to

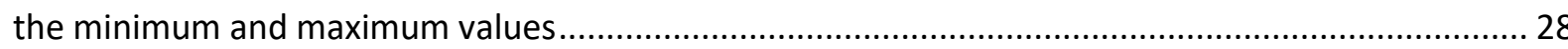

Figure 11: Percent average vegetative cover by cover crop species in 2016; bold line represents the median value, boxes encompass 25 th to 75 th percentile, and vertical lines extend to the minimum and maximum values

Figure 12: Percent average vegetative cover by cover crop species in 2017; bold line represents the median value, boxes encompass 25 th to 75 th percentile, and vertical lines extend to the minimum and maximum values. Vegetative cover was sampled three times in 2017 30

Figure 13: Harpalus beetle used for the experiment

Figure 14: Example set up of a beetle cage for the no-choice seed preference experiment: A.) Seed dish with 50 seeds B.) Moist cotton C.) Soil collected from field site.....

Figure 15: Percent consumption (out of 50 seeds) of weed and cover crop seeds measured over five consecutive days; bold line represents the median value, boxes encompass $25^{\text {th }}$ to $75^{\text {th }}$ percentile, and vertical lines extend to the minimum and maximum values 
CHAPTER ONE: CARABID RESPONSE TO BROADCAST INTERSEEDING AND VEGETATIVE COVER 


\section{Introduction}

Over half of the continental United States is comprised of agricultural land (Bigelow \& Borchers, 2017), and the prevalence of major crops grown as monocultures within these landscapes reduce biodiversity. Using cover crops is one potential strategy to promote diversity and environmental benefits (Clark, 2007). Though cover crops are not directly economically profitable, if interseeded in corn they can be used as supplemental forage for livestock that graze on corn stalks. However, the best methods associated with interseeding cover crops are not thoroughly understood, especially in semi-arid climates. Seeding method and cover crop diversity may influence cover crop establishment, corn and forage yield, and impact abundance and diversity of other organisms in the ecosystem.

Cover crops can provide a plethora of ecosystem services within agronomic systems. In contrast to cash crops, cover crops are traditionally incorporated into crop rotations during off seasons and used for environmental benefits rather than profitability. Cover crops have been documented to improve nutrient cycling, enhance soil health, prevent soil erosion, suppress weeds, pests, and pathogens, and host beneficial insects (Lu, Watkins, Teasdale, \& Abdul-Baki, 2000; Snapp et al., 2005). A recent review of the potential of cover crops as a strategy to adapt to climate change found that cover crops may help to reduce the effects of climate change through mitigation of warming and reduction of vulnerability to erosion, drought, extreme rain events and other landscape effects caused by climate warming (Kaye \& Quemada, 2017). Despite their potential for increased ecosystem services, adoption of cover crops in the Unites States is limited (Wade, Claassen, \& 
Wallander, 2015). This is likely due to the negative aspects associated with implementing cover crops. Potential tradeoffs to incorporating cover crops include financial limitation, water limitation to cash crops, increased pest and pathogen risk, and more time and labor associated with management of cover crops (Clark, 2007). Water use by cover crops is especially a concern in Wyoming due to its semi-arid climate. When selecting cover crop species, it is important for land managers to identify their objectives and to learn which species work best for their particular climate and soil type (Roth \& Curran, 2015).

There are two common methods for interseeding crops; seeds are either placed in the ground (i.e., drilling), or they are broadcast on the surface (i.e., aerial). Placing seeds directly in the soil could potentially be beneficial for larger-seeded species to establish. However, specialized equipment is required to accomplish this method of seeding (Wilson, Allan, \& Baker, 2014). This method also causes more soil disturbance and could negatively affect establishment of certain cover crop species. Conversely, broadcast seeding causes less soil disturbance, and larger areas can be seeded in less time, for instance by plane. However, seeds broadcast on the soil surface could have patchier establishment and potentially leave seeds vulnerable to seed predators (Wilson et al., 2014; Wilson, Baker, \& Allan, 2013). Impacts of interseeding cover crops on establishment may differ depending on the species of cover crops planted. A study in an organic production in New York found that interseeded legumes in corn established poorly and produced less biomass compared to annual ryegrass and creeping red fescue (Hively \& Cox, 2001). Another challenge associated with determining ideal seeding method is timing of interseeding. In a study in Ontario, cover crops (alfalfa, hairy vetch, oat and rapeseed) interseeded at early stages of corn growth (V4-V6) had 33\% greater 
biomass production compared to cover crops interseeded at later stages of corn growth (V10V12) (Belfry \& Van Eerd, 2016). Variables associated with effective interseeding are further convoluted when planting seed mixtures.

The ecosystem services associated with cover crops are varied and dependent upon several factors. Primary variables include climate type and cover crop species planted. However, planting cover crops as either single species or mixtures can also significantly affect management outcomes. The most commonly used cover crops in the United States fall within one of three functional group categories: legumes, grasses, or brassicas (Lu et al., 2000). In general, different ecosystem services are associated with a particular functional group. For example, legume cover crops can convert atmospheric nitrogen into soil nitrogen, which can be used by future cash crops (Clark, 2007). However, the type of species within a functional group can also affect ecosystem services. The quantity and quality of biomass yield is variable among cover crop species (Lu et al., 2000). Planting cover crops as either single species or mixtures can also influence cover crop success. Across ecosystems, there is a positive correlation between biodiversity and ecosystem functioning (Buchmann, 2006) when species richness is the metric for measuring diversity. There is weak evidence for a relationship between species richness and ecosystem functioning within an agronomic setting. Scientists in New Hampshire studied the productivity of cover crop mixtures by seeding single species of buckwheat, mustard, sorghum-sudan grass, cereal rye, and field pea and a mixture of all five species; biomass production, weed suppression, spatial and temporal stability and carry-over effects were measured (Smith, Atwood, \& Warren, 2014). This study found that mixtures produced more biomass compared to monocultures, but did not provide 
any enhancement in weed suppression, biomass stability, or productivity of subsequently planted cash crops. Functional group diversity may have a more significant impact on ecosystem benefits than species richness. A recent study in the Northeastern United States demonstrated that the simultaneous occurrence of multiple ecosystem services-- such as weed suppression, nitrogen retention, and biomass production--was more correlated with functional diversity (Finney \& Kaye, 2016). Functional diversity of plants in monocultures and polycultures may also play a significant role in arthropod community structure in agroecosystems.

Variables such as seeding method and disturbance may not only affect crop yield, but also impact interactions among other organisms in the ecosystem. Literature suggests that invertebrate seed predators have a significant impact on seed presence within agroecosystems (Blubaugh \& Kaplan, 2016; Holland, 2002), although this impact varies dependent upon location and time of season. Ground beetles (Coleoptera: Carabidae) are abundant within agricultural settings and have a substantial effect on weed seeds present in seed bank. This is in part because seeds are an optimum diet for larval development and adult fecundity (Jorgensen \& Toft, 1997; Saska, 2008). Physiological factors, such as carabid morphology, taxonomic constraints, and seed size have been shown to affect seed preference (Honek, Martinkova, Saska, \& Pekar, 2007). Ecosystem traits also influence seed preference, including time of season, prey abundance, soil characteristics, and whether seeds are buried or on the soil surface. An experiment conducted in Maine showed that the granivorous carabid, Harpalus rufipes, predated more frequently on the seeds of wild mustard (Sinapis arvensis) when there was minimal soil disturbance and when seeds were available on the soil surface 
(Harrison \& Gallandt, 2012). A laboratory experiment testing the effects of season on seed predation by the carabids Harpalus affins and Harpalus distinguendus showed that seed consumption increased in spring and summer (April-June), then gradually began to decrease in the fall (June-October) (Honek, Saska, \& Martinkova, 2006). Past studies demonstrated carabid preference of various species of weed seeds (Johnson \& Cameron, 1969; Petit, Boursault, \& Bohan, 2014). However, there is a general lack of studies exploring carabid preference for crop seeds. If carabids share similar preference for seeds, cover crop seeds left on the soil surface may potentially be vulnerable to predation.

Several studies demonstrated that carabids respond to vegetative cover, but most focus on weeds. For instance, (Brooks et al., 2012) found that functional trait diversity of weeds influenced carabid population dynamics. Vegetative cover provided by weeds in an organically managed farm in central Germany encouraged carabid activity-density- a metric measuring activity of ground-dwelling arthropods relative to its population abundance- by providing shelter, food resources, and favorable microclimate (Diehl, Wolters, \& Birkhofer, 2012). Fewer studies have explored how crop vegetation, such as cover crops, effect carabids. Less than $2 \%$ of total cropland in the US is used for cover cropping (Wade, Claassen, \& Wallander, 2015), and the ecological impacts of using cover crops still needs to be explored. Cover crops are a low-intensity, sustainable management practice that has been shown to increase the abundance of beneficial ground-dwelling arthropods, such as carabids (Lundgren, Shaw, Zaborski, \& Eastman, 2006). Transitioning organic systems that incorporate cover crops have seen higher activity-density of carabids (Carmona \& Landis, 1999). In Stillwater, Maine, higher activity-density of the granivorous carabid Harpalus 
rufipes was more frequent in plots with cover crops compared to fallow plots (Shearin, Reberg-horton, \& Gallandt, 2008). A study in Indiana found that vegetative cover provided by cover crops, specifically red clover, increased activity and weed seed predation by granivorous carabids (Blubaugh, Hagler, Machtley, \& Kaplan, 2016) However, it is still unclear whether carabids respond more to taxonomic plant diversity or functional plant diversity within cover crop mixtures.

In this study, I explored how functional diversity of interseeded cover crops affects cover crop biomass production and ground beetle activity-density. The objectives of this study are to: 1) quantify the effect of functional diversity on cover crop productivity, 2.) explore how functional diversity and vegetative cover effect carabid activity-density, and 3) determine the extent to which animals predate on crop seed. 


\section{Materials and Methods}

\subsection{Field Site}

The field experiment was conducted in Goshen County at an elevation of 1,272 m at the James C. Hageman Sustainable Agriculture Research and Extension Center (SAREC) in Lingle, WY (45.9156" N, 24.8784”W). The experimental field was managed according to SAREC farm crew's norms for production corn. The experiment was replicated over two years, in 2016 and 2017. In 2016, manure was applied on March 18, 2016 at a rate of 20 tons/acre. There was no manure applied to the field site in 2017. Spring field preparation activities for both 2016 and 2017 included discing and cultivation. A fertilizer blend of 2850-44 and 25 sulfur was applied on April 11, 2016. An additional 145.71 kg of nitrogen per

hectare was added on June 15, 2016. On May 1, 2017, the fertilizer blend of 20-60-0 and 50 sulfur was applied. An additional $134.5 \mathrm{~kg}$ of nitrogen per hectare was added on June 29, 2017. On April 23, 2016 and May 10, 2017, field corn was planted at a rate of 84,015 seeds/hectare in 30-inch rows. Glyphosate (Roundup PowerMax) plus the adjuvant Hel-Fire was applied for weed control on June 3, 2016 and June 13, 2017. To avoid any negative impacts on cover crop growth, no subsequent herbicide applicators were used for weed management (Meeks, 2016). The field was irrigated as needed for production purposes from May 21 to October 18 in 2016 and from June 9 to September 12 in 2017.

A randomized complete block design was used for the experimental layout to account for variability within the field site, with blocks arranged at different distances away from the field edge. Cover crop species used for the study included: purple top turnip (Brassica rapa), 
rapeseed (Brassica napus), winter wheat (Triticum aestivum), triticale (Triticale hexaploide L.), Austrian winter pea (Pisum sativum), and red clover (Trifolium pretense). These species were chosen for the experiment because they have been shown to do well in the high elevation and semi-arid climate associated with the site(Meeks, 2016), and have potential use for fall or spring grazing. These six cover crop species are also representative of three different functional groups: legumes (Austrian winter pea and red clover), brassicas (turnip and rapeseed), and grasses (winter wheat and triticale).

I seeded cover crops in standing corn at the V6 stage of growth on June 24, 2016 and July 5, 2017. Seeds were broadcast on the surface of the field by hand at the outer edges of the plot to avoid foot traffic. Individual plot sizes measured $9.14 \mathrm{~m}$ x $9.14 \mathrm{~m}$ with $4.57 \mathrm{~m}$ buffers in all direction between plots. Buffer areas included only corn. There were a total of seven treatments: single species of Austrian pea, turnip, and winter wheat; two three-species mixtures; one six-species mixture; and a control with no cover crops added. In 2016, these treatments were replicated four times. In 2017, I increased the replicates to five. Seeding rates were determined as per the recommendations of White, et. al (2016) (Table 1). Brassica species are highly competitive and must have reduced seeding rates within mixtures to prevent them from outcompeting other plants (USDA, 2010). Legumes are weak competitors and must have proportionally higher seeding rates in mixtures (USDA, 2010). 
Table 1: Seeding treatments based on e-Organics seeding recommendations (White, et al., 2016)

\begin{tabular}{lc}
\hline Single species & $\mathbf{k g} / \mathbf{h e c t a r e}$ \\
\hline Turnip & 4.5 \\
Austrian pea & 67.3 \\
Winter wheat & 125.5 \\
& \\
\hline Three species mixture & $2.9-11.2-82.9$ \\
\hline Turnip + red clover + winter wheat & $2.9-56-82.9$ \\
Rapeseed + pea + triticale & Half of rates from 3 spp mix \\
\hline Six species mixtures & $1.45-1.45-28-5.6-41.5-41.5$ \\
\hline Turnip + rapeseed + Austrian pea + red & nothing \\
\hline clover + triticale + winter wheat & \\
\hline
\end{tabular}

\subsection{Biomass Sampling}

Aboveground biomass was collected in the field October 13, 2017. I was unable to collect biomass in 2016 due to damage from a hailstorm in late July. Quadrats $(0.33 \times 0.33 \mathrm{~m})$ were used to randomly sample between cornrows of each plot. Samples were at least $1.5 \mathrm{~m}$ from plot edges. Biomass samples were taken using rice knives to cut samples at the soil surface. Two samples were taken per plot, and 70 total samples were taken ( 2 samples x 7 treatments x 5 blocks). Samples were sorted and weighed in the field by plant species for single species and three-species mixtures. Six-species mixtures were sorted by functional group; triticale and wheat were recorded as grasses, red clover and Austrian pea were recorded as legumes, and rapeseed and turnip were recorded as brassicas. Weed samples of the three most prevalent weed types within the field plot were also weighed: Eastern black nightshade and hairy nightshade (Solanum ptycanthum and S. physalifolium), redroot pigweed (Amaranthus retroflexus), and lambsquarters (Chenopodium album). Both species of nightshade were present within the field plot and sampled together. A subset of the fresh- 
weight samples (two samples per treatment) were taken back to the lab and dried in an oven at $60^{\circ} \mathrm{C}$ for 48 hours. Weight was measured for each dried sample, and proportion of water was calculated for each species based on in-field fresh weight data. These calculations were used to estimate dry weight for all samples.

Total biomass, crop biomass and weed biomass were calculated for each plot. Total biomass included biomass for both cover crops species and weed species. Crop biomass included the biomass for cover crop species only. Weed biomass measured the biomass of lambsquarter, redroot pigweed, hairy nightshade, and Eastern black nightshade.

\subsection{Seed Assays}

Seed assays were used to estimate levels of seed predation from vertebrate and invertebrate seed predators. Seed assays were installed in the field on the same day as cover crop seeding. In 2016, seed assays were placed in the field on June 27 and collected June 29. In 2017, seed assays were placed in the field July 5 and collected July 7.

Seed species used for seed assays included: purple-top turnip, rapeseed winter wheat, triticale, Austrian pea, and red clover. These cover crop species were used because they correspond to seeding treatments within the field site. Seed assays contained 60 seeds of either a single species or a mixture. Single seed species included purple top turnip, Austrian pea, and winter wheat. Two three-species mixtures included twenty seeds each of either a turnip-clover-wheat or a rapeseed-peas-triticale mixture. Six-species mixtures contained 10 seeds each of all six species. In 2017, the legume species within the three-species mixtures were inadvertently switched, so three-species treatments for 2017 are turnip-pea-wheat and rapeseed-clover-triticale. Seed treatments were counted and pressed onto inverted petri dishes 
covered with double-sided mounting film (Birthisel, Gallandt, Jabbour, \& Drummond, 2015). Seeds were distributed evenly throughout the plate and sand was poured on the sticky portions of the seed plate to prevent seed predators from sticking to the seed assays.

To account for vertebrate and invertebrate seed predator presence, we used two different treatments: exclosure and open assays. For the open treatment, seed dishes were accessible to both vertebrate and invertebrate seed predators and had no barriers to seed access (Figure 1A). For the exclosure treatment, seed dishes had a wire cage surrounding the seed dish with holes $(2.54 \times 2.54 \mathrm{~cm})$ only accessible by invertebrates (Figure 1B). Seed dishes surrounded with tight window screen mesh that restricted access to seed by both invertebrate and vertebrate seed predators served as controls. Seed dishes (single species or mixed) correlated with the seeding treatment of each plot. Seed assays were excluded from control plots, which were not seeded with cover crops. Seed dishes were collected after 48 hours, carefully placed in sealed plastic bags, and returned to the lab to count number of seeds remaining. 


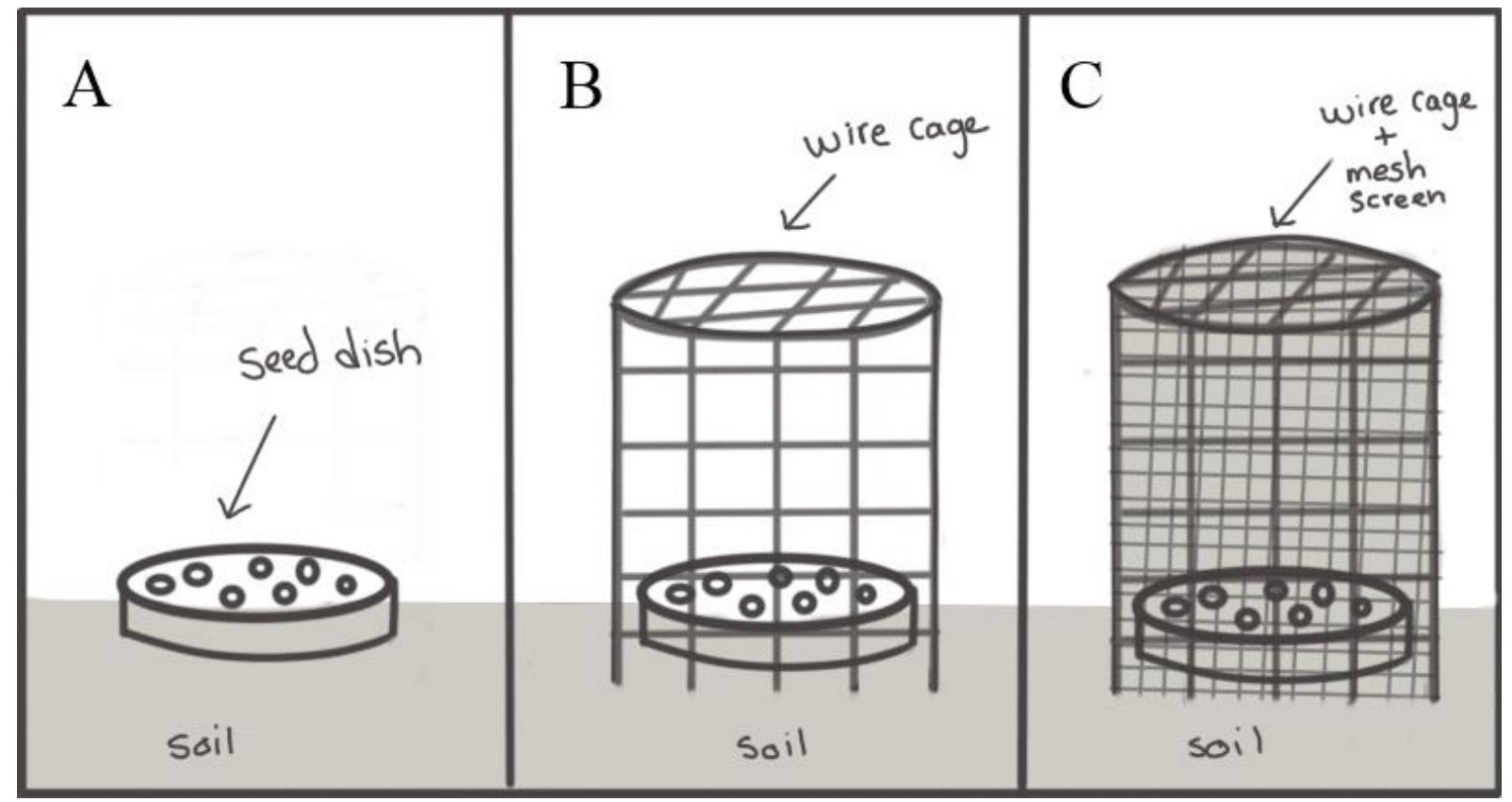

\subsection{Carabid sampling}

Carabid activity-density was estimated using pitfall traps. Activity-density is a metric used to determine population abundance and relative activity of ground-dwelling arthropods (Lester \& Morrill, 1988). Pitfall traps were constructed by placing a red Solo cup (height=12 $\mathrm{cm}$, diameter $=6 \mathrm{~cm}$ ) in the ground flush with the soil surface. A $118 \mathrm{~mL}$ sample cup was placed inside the Solo cup and filled with $59 \mathrm{~mL}$ of soapy water. Funnels were placed on top of the solo cup to prevent captured arthropods from crawling out. Pitfall traps were left out for time intervals of 48 hours. Two pitfall traps were randomly placed in each plot at least $1.524 \mathrm{~m}$ from the plot edge. Within the experimental area, there was a total of 56 pitfall traps $(2$ per plot $\mathrm{x} 7$ treatment plots $\mathrm{x} 4$ blocks) in 2016, and 70 pitfall traps ( 2 per plot $\mathrm{x} 7$ treatments $\mathrm{x} 5$ blocks) in 2017. 
Pitfall traps were placed in the field during seeding of the field site (Figure 2) and after seedling emergence (Figure 3). In 2016, pitfall traps were placed in the field from June 27-29 and July 16-18. A third pitfall sample was not taken for 2016 due to severe field damage from the hailstorm in late July. In 2017, pitfall traps were placed in the field July 5-7, July 31 - August 2, and August 22-24. After collection, pitfall samples were transferred to the lab and stored in a refrigerator. Samples were sieved, and all beetles were pinned. Pinned beetles were later identified by family and sorted as either carabid or non-carabid. 
Figure 2: Pitfall trap in the field after broadcast seeding in 2017

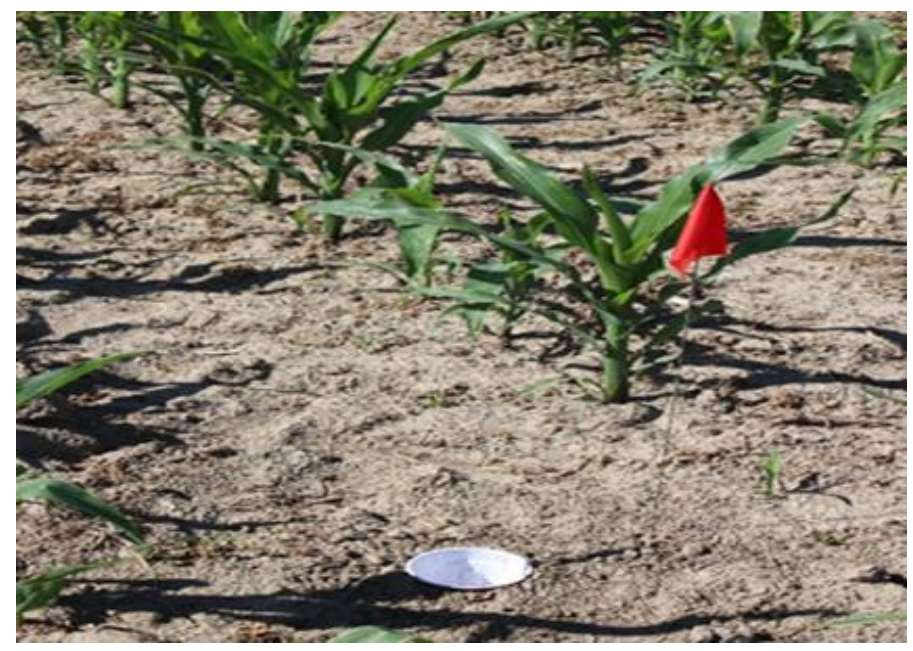

Figure 3: Pitfall trap in the field after seedling emergence in 2017

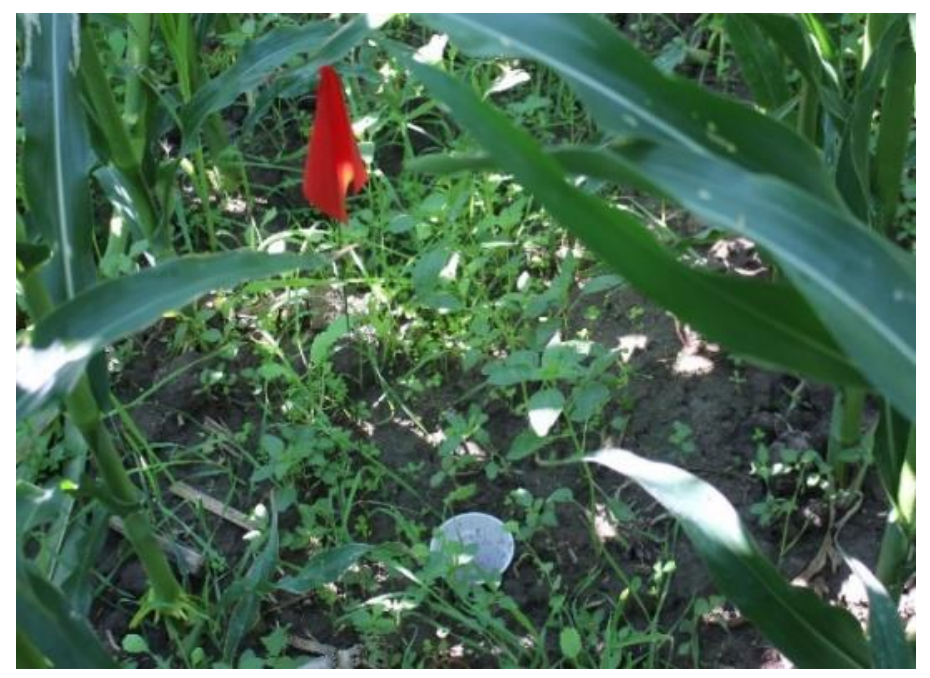

\subsection{Vegetative Cover}

Vegetative cover was estimated using photos taken above quadrats in the field on July 18, 2016, July 31, 2017, and August 22, 2017, dates when pitfall samples were collected. Quadrats measured $0.33 \times 0.33 \mathrm{~m}$ and were randomly placed within field plots. Quadrats that were not at least $1.5 \mathrm{~m}$ from the plot edge or $0.9 \mathrm{~m}$ from a pitfall trap were randomly 
reassigned. Two ground cover pictures were taken per plot. Using SamplePoint software (Booth, Cox, \& Berryman, 2006), photographs were analyzed with a 9x9 grid size to assess the percent composition of cover crop species, weeds, leaf litter and bare ground.

\subsection{Data Analysis}

\section{Cover Crop Biomass}

An analysis of variance (ANOVA) was used to test if aboveground biomass was affected by cover crop treatment. Assumptions for ANOVA were tested using Shapiro-Wilk's test for normality. Total biomass, crop biomass, weed biomass were log transformed to meet the requirements for normality of residuals and homoscedasticity. Tukey's honest significant difference (HSD) test was used to conduct pairwise comparisons when the ANOVA test indicated a significant difference $(\alpha<0.05)$. The average amount of biomass contributed by each cover crop species within the 3-species mixtures and each of the three functional groups within the 6-species mixtures was calculated.

\section{$\underline{\text { Seed Assay }}$}

To analyze seed assay data, I used a binomial distribution to model seed remaining on seed dishes versus seeds removed. I included cover crop species, treatment, and block as predictors, with an interaction between species and treatment. The variable "treatment" refers to the three treatments - open, exclosure, and control — used for the experiment. I used a generalized linear model in R studio (R Core Team, 2016). Data are presented in boxplots generated using the package ggplot2 (Wickham, 2009).

\section{Carabid Activity-density}


Carabid activity-density was estimated using a repeated measures mixed-effects model in R studio (R Core Team, 2016) using the statistical packages lmer (Bates, Bolker, \& Walker, 2015), and lmerTest (Kuznetsova, Brockhoff, \& Christensen, 2017). I included cover crop species, block, and date as predictors, with an interaction between species and date.

\section{$\underline{\text { Vegetative Cover }}$}

To analyze the response of carabids to vegetative cover, I performed an ANOVA. For the 2016 pitfall date, I included the predictors block, average vegetative cover, and cover crop species with an interaction between average vegetative cover and cover crop species. Date was not included in the model because vegetative cover was only collected for one date in 2016.

To analyze 2017 pitfall data, I ran a mixed effects model with repeated measures using the statistical packages lmer (Bates, Bolker, \& Walker, 2015) and lmerTest (Kuznetsova, Brockhoff, \& Christensen, 2017). I included species, date, block, average vegetative cover, and the interaction between average vegetative cover and species as predictors.

Analysis were used to answer the following research questions:

- Does functional diversity of cover crops effect biomass production?

- Does composition of broadcast seeds influence seed predation rates?

- Does seed removal rate vary between vertebrate and invertebrate predators?

- Does functional diversity of cover crops influence carabid activity-density?

- Do carabids respond to broadcast seeding of cover crops?

- Do carabids respond to vegetative cover provided by cover crops? 


\section{Results}

Treatment abbreviations used to report results are as follows: six-species mixture (6sppmix), rapeseed-clover-triticale (3RapCloTri), turnip-pea-wheat (3TurPeaWW), winter wheat (WW), turnip (turnip) and Austrian pea (pea).

Does functional diversity of cover crops effect biomass production?

Cover crop species had an effect on total biomass $(\mathrm{p}=0.003)$ and crop biomass $(\mathrm{p}<0.0001)$, but not weed biomass $(\mathrm{p}=0.52)$ (Table 8-10). According to Tukey's HSD, the significant pairwise differences for total biomass production were between the control and the following treatments: turnip $(\mathrm{p}=0.03)$, wheat $(\mathrm{p}=0.04)$, the three-species mixture with turnippea-wheat $(\mathrm{p}<0.001)$, and the six-species mixture $(\mathrm{p}=0.02)$. For crop biomass, the significant pairwise differences were between the control and turnip ( $\mathrm{p}<0.0001)$, wheat $(\mathrm{p}<0.0001)$, pea $(\mathrm{p}<0.0001)$, both three-species mixtures with turnip-pea-wheat $(\mathrm{p}<0.0001)$ and rapeseedclover-triticale $(\mathrm{p}<0.0001)$, and the six-species mixture $(\mathrm{p}<0.0001)$.

For both total biomass and crop biomass, the three-species mixture treatment with turnip-pea-wheat produced the most biomass. For total biomass, the average biomass for the three-species mixtures was $3433 \mathrm{~kg} / \mathrm{ha}$ (Table 2) and for crop biomass, the average was $3334.43 \mathrm{~kg} / \mathrm{ha}$ (Table 3). Within the three-species mixture with turnip-pea-wheat, turnip contributed the majority (78.7\%) of biomass produced (Table 4). In the three-species mixture treatment with clover-rapeseed-triticale, clover contributed the majority $(70.45 \%)$ of biomass. 
In the six-species mixture, brassicas (turnip and rapeseed) contributed the most biomass

(Table 4).

Figure 4: Total biomass (log transformed $\mathrm{kg} / \mathrm{ha}$ ) of seven interseeded cover crop treatments in 2016; bold line represents the median value, boxes encompass $25^{\text {th }}$ to $75^{\text {th }}$ percentile, and vertical lines extend to the minimum and maximum values

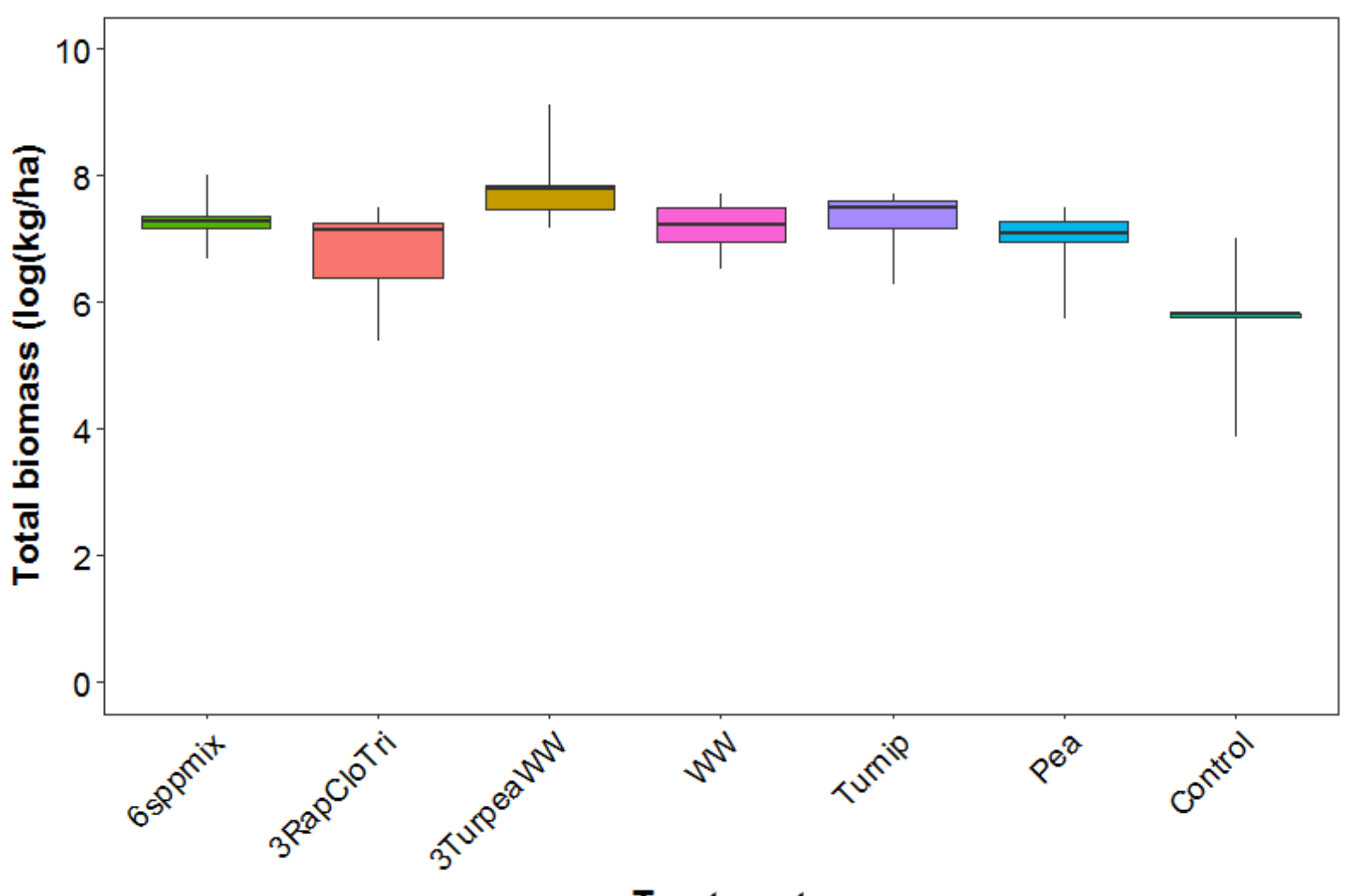

Treatment 
Figure 5: Cover crop biomass (log transformed $\mathrm{kg} / \mathrm{ha}$ ) of seven interseeded cover crop treatments in 2016; bold line represents the median value, boxes encompass $25^{\text {th }}$ to $75^{\text {th }}$ percentile, and vertical lines extend to the minimum and maximum values

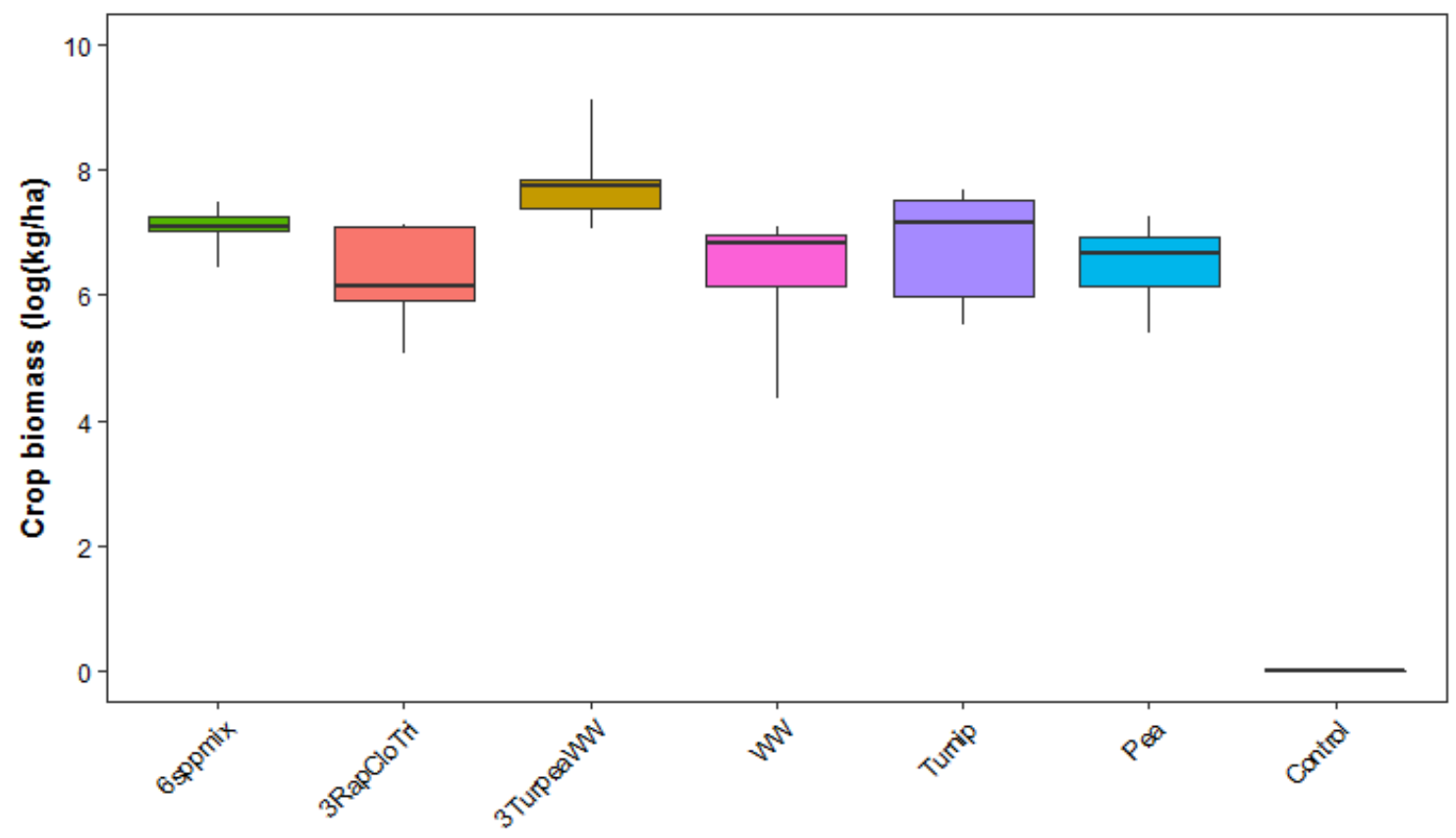

Treatment

Figure 6: Weed biomass (log transformed $\mathrm{kg} / \mathrm{ha}$ ) of seven interseeded cover crop treatments in 2016; bold line represents the median value, boxes encompass $25^{\text {th }}$ to $75^{\text {th }}$ percentile, and vertical lines extend to the minimum and maximum values

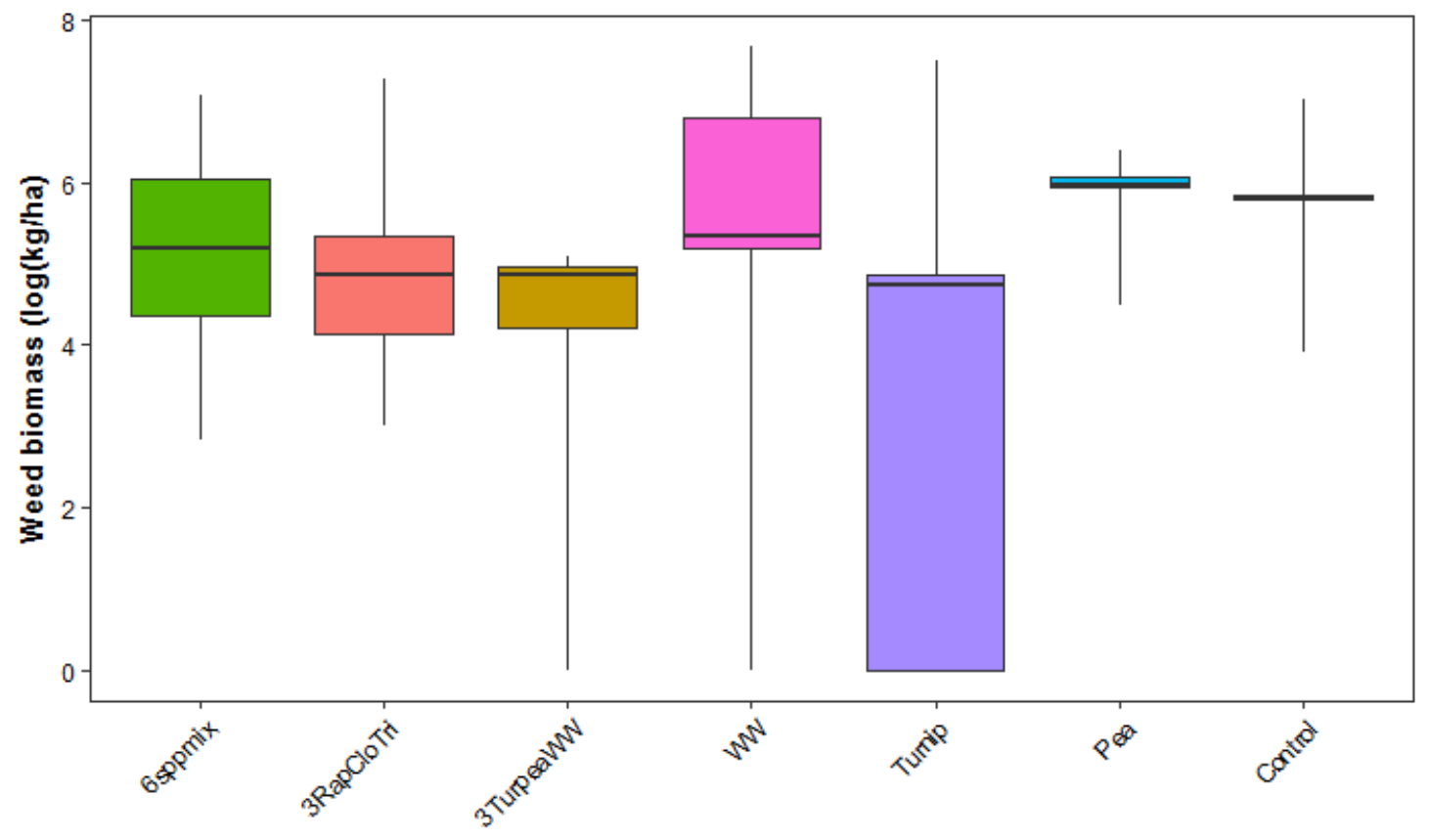

Treatment 
Table 2: Average total biomass production and standard deviation by cover crop treatment.

\begin{tabular}{lcc}
\hline Treatment & $\begin{array}{c}\text { Total Biomass } \\
\text { Average }(\mathrm{kg} / \mathrm{ha})\end{array}$ & Std. Deviation \\
\hline 6sppmix & 1612 & 811 \\
3RapCloTri & 1056 & 636 \\
3TurPeaWW & 3433 & 3238 \\
Turnip & 1583 & 689 \\
Pea & 1151 & 546 \\
Wheat & 1423 & 604 \\
Control & 428 & 394 \\
\hline
\end{tabular}

Table 3: Average crop biomass and standard deviation by cover crop treatment

\section{Crop Biomass}

\begin{tabular}{lcc} 
Treatment & Average $(\mathrm{kg} / \mathrm{ha})$ & Std. Deviation \\
\hline 6sppmix & 1243 & 433 \\
3RapCloTri & 688 & 502 \\
3TurPeaWW & 3334 & 3263 \\
Turnip & 1180 & 838 \\
Pea & 776 & 461 \\
Wheat & 742 & 464 \\
Control & 0 & 0 \\
\hline
\end{tabular}

Table 4: Average biomass and percent composition contributed by species and functional groups within three-species and sixspecies mixtures

\begin{tabular}{cccc}
\hline Treatment & Species & Avg Biomass (g) & Composition (\%) \\
\hline \multirow{2}{*}{ 3TurPeaWW } & Turnip & 57.78 & 78.77 \\
& Pea & 6.63 & 9.04 \\
& Wheat & 8.93 & 12.18 \\
\hline \multirow{2}{*}{ 3CloRapTri } & Clover & 10.67 & 70.45 \\
& Rapeseed & 0.94 & 6.21 \\
& Triticale & 3.53 & 23.34 \\
\hline Treatment & Functional Group & Avg Biomass (g) & Composition (\%) \\
\hline \multirow{2}{*}{ 6sppmix } & Brassicas & 14.01 & 51.7 \\
& Legumes & 7.81 & 28.53 \\
& Grasses & 5.53 & 20.29 \\
\hline
\end{tabular}


Does the composition of broadcast seeds influence seed predation rates?

In 2016, levels of seed predation varied with cover crop species $(\mathrm{p}<0.001)$, seed exclosure treatments $(\mathrm{p}<0.001)$, block $(\mathrm{p}=0.01)$, and the interaction between cover crop species and exclosure treatments $(\mathrm{p}=0.04)$ (Figure 7). The open treatment for the threespecies mixture with rapeseed-clover-triticale had the highest rate of seed removal, with rapeseed having the highest average removal within the mixture (Table 5). The six-species mixture, incorporating all seed species, had the highest rate of removal for exclosure treatments, with legume species (clover and pea) having the highest average seed removal (Table 5). Within the single species treatments, turnip had the highest rate of removal for both open and exclosure treatments.

In 2017, levels of seed predation varied with cover crop species $(\mathrm{p}<0.001)$, treatment ( $\mathrm{p}<0.001)$, block $(\mathrm{p}=0.03)$, and the interaction between cover crop species and treatment $(\mathrm{p}$ $<0.001$ ) (Figure 8). The open treatment for turnip as a single species had the highest rate of seed removal. The three-species mixture with turnip-clover-wheat had the highest removal rate for exclosure treatments, with clover having the highest average removal within the mixture (Table 6). 
Figure 7: Removed seeds (out of 60 total seeds from seed assay) were measured for three treatments in 2016; bold line represents the median value, boxes encompass $25^{\text {th }}$ to $75^{\text {th }}$ percentile, and vertical lines extend to the minimum and maximum values

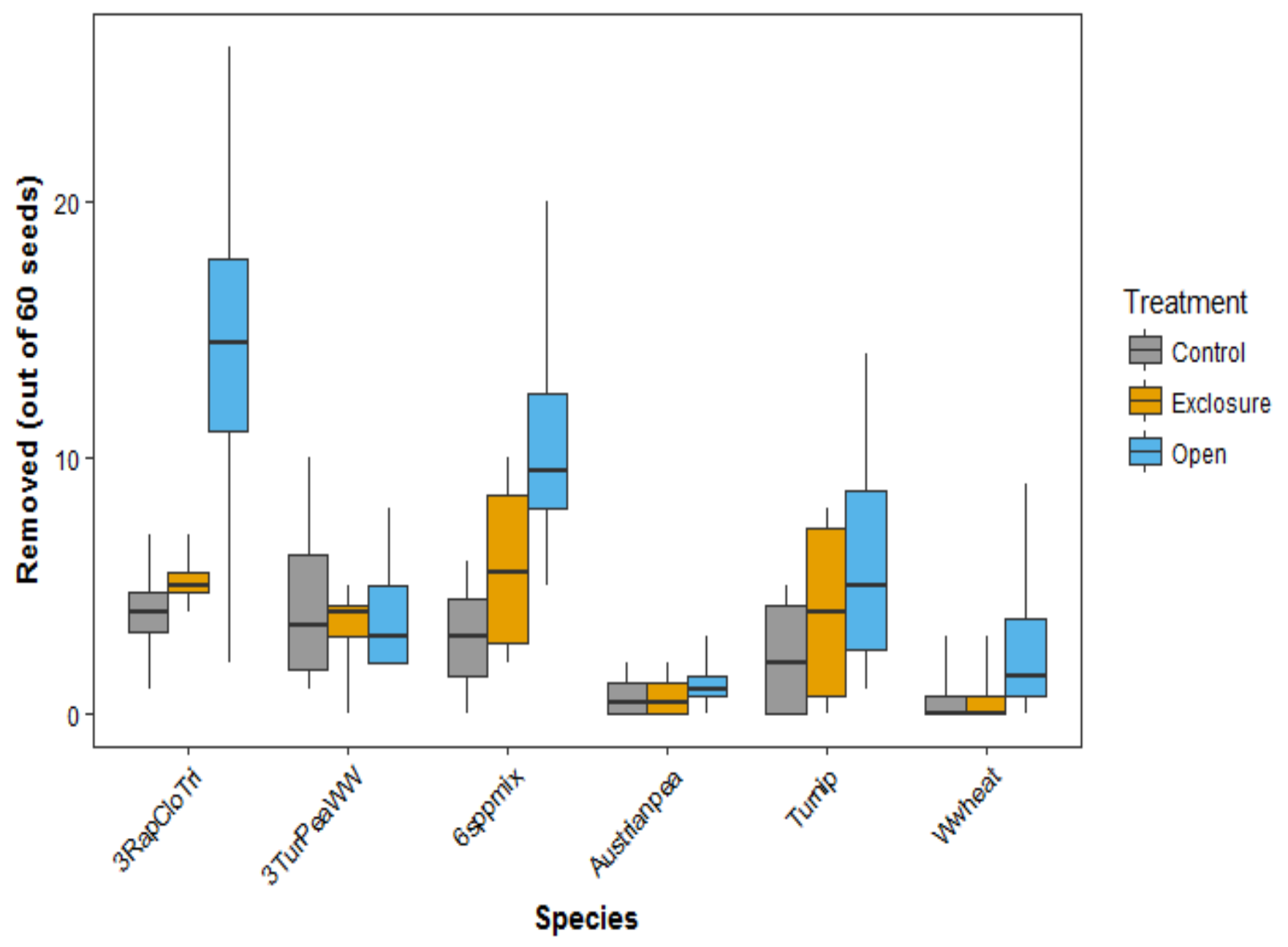


Figure 8: Removed seeds (out of 60 total seeds from seed assay) were measured for three treatments in 2017; bold line represents the median value, boxes encompass $25^{\text {th }}$ to $75^{\text {th }}$ percentile, and vertical lines extend to the minimum and maximum values

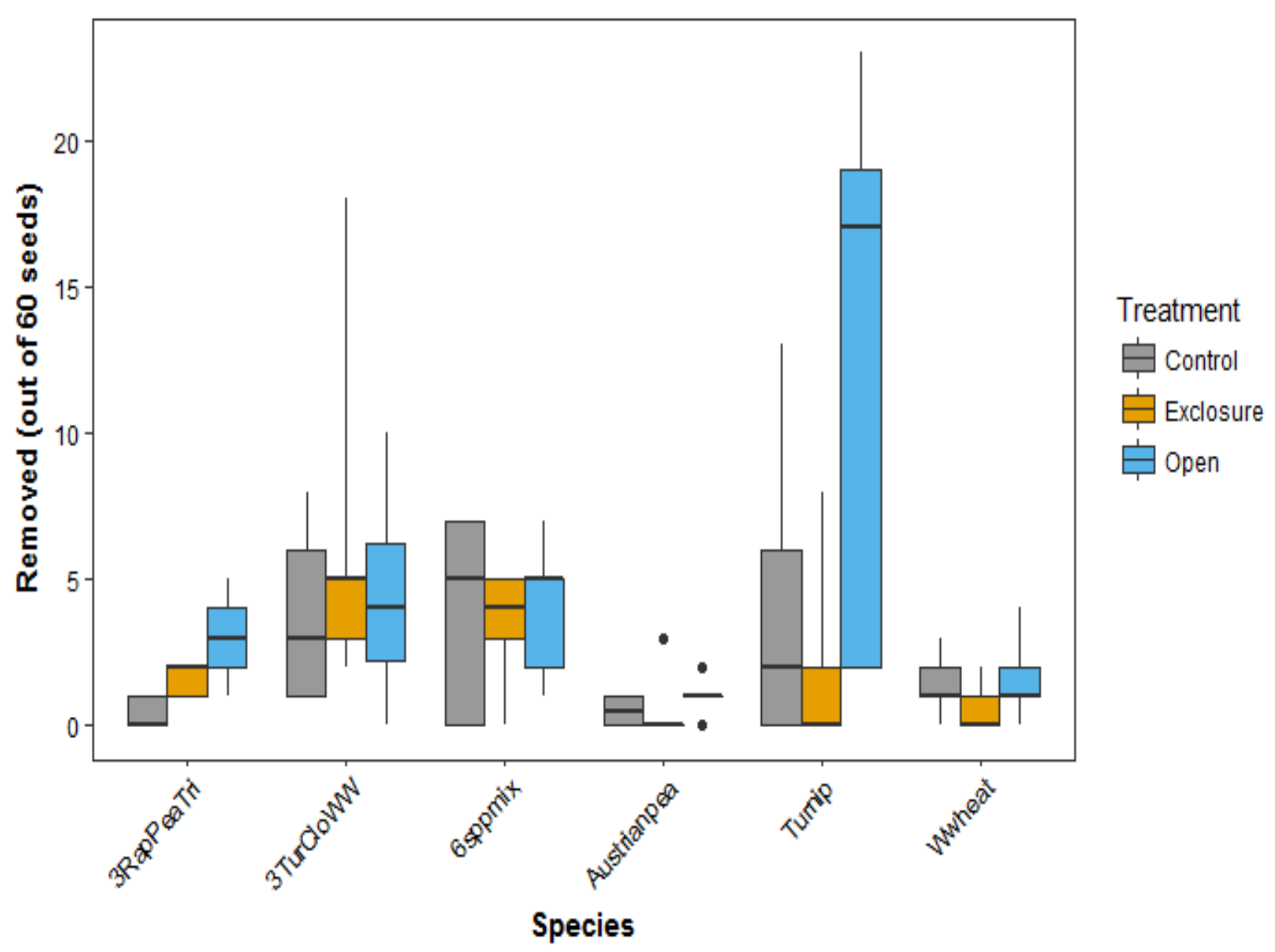


Table 5: 2016 seed assay; average removal of seeds by species within mixtures. Three-species mixtures had 20 seeds per species, while six-species mixtures had 20 seeds per functional group (10 seeds per species)

\begin{tabular}{cccccc}
\hline Treatment & Species & Open & \multicolumn{3}{c}{ Exclosure } \\
\hline \multirow{3}{*}{ 3RapCloTri } & & Avg. Removal & SE & Avg. Removal & SE \\
& rapeseed & 7.5 & 3.5 & 1.25 & 0.56 \\
& clover & 4 & 1.75 & 3.5 & 0.25 \\
& triticale & 2.75 & 1.23 & 0.5 & 0.25 \\
\hline \multirow{3}{*}{ 3TurPeaWW } & turnip & 2.5 & 0.86 & 1.5 & 0.77 \\
& pea & 0.5 & 0.25 & 1 & 0.35 \\
& wheat & 1 & 0.63 & 0.75 & 0.42 \\
\hline \multirow{3}{*}{ 6sppmix } & Functional Group & & & & \\
& Brassicas & 5.75 & 0.44 & 2.5 & 0.44 \\
& Grasses & 0.75 & 0.22 & 0.25 & 0.22 \\
& Legumes & 4.5 & 1.59 & 3 & 1.59 \\
\hline
\end{tabular}

Table 6: 2017 seed assay; average removal of seeds by species within mixtures. Three-species mixtures had 20 seeds per species, while six-species mixtures had 20 seeds per functional group (10 seeds per species).

\begin{tabular}{ccclcl}
\hline Treatment & Species & \multicolumn{2}{c}{ Open } & \multicolumn{3}{c}{ Exclosure } \\
\hline \multirow{3}{*}{ 3RapPeaTri } & & Avg. Removal SE & Avg. Removal SE \\
& rapeseed & 1.8 & 0.6 & 0.2 & 0.2 \\
& pea & 0 & 0.37 & 0.8 & 0.37 \\
& triticale & 0.4 & 0.24 & 0.6 & 0.2 \\
\hline \multirow{3}{*}{ 3TurCloWW } & turnip & 0.75 & 0.43 & 1.8 & 0.58 \\
& clover & 3.75 & 1.94 & 4 & 2.76 \\
& wheat & 0.5 & 0.44 & 0.8 & 0.58 \\
\hline \multirow{3}{*}{ 6sppmix } & Functional Group & & & & \\
& Brassicas & 0.4 & 0.24 & 0.4 & 0.74 \\
& Grasses & 0.6 & 0.4 & 0.2 & 0.8 \\
\hline
\end{tabular}


Does seed removal rate vary between vertebrate and invertebrate predators?

Treatment (open and exclosure) was a significant predictor for seed removal rates $(\mathrm{p}<0.001)$. In general, open treatments, which were accessible to both vertebrate and invertebrate seed predators, had higher rates of seed removal than exclosure treatments, which were only accessible to invertebrates.

Does functional diversity of cover crops influence carabid activity- density?

Date was a significant predictor for carabid abundance in 2016 ( $\mathrm{p}<0.001)$ (Table 15). Carabid activity-density was higher in July compared to June (Figure 9). There was a nonsignificant trend of higher carabid activity-density between the cover crop species $(\mathrm{p}=0.06)$. In June, at the time of seeding, the single seeded pea treatment and the control treatment both had the highest carabid activity-density. The six-species mixture had the highest activitydensity of carabids in July.

In 2017, date was also a significant predictor for carabid abundance $(\mathrm{p}<0.001)$. Activity-density of carabids was highest for the last pitfall date in late August (Figure 10). Cover crop species $(\mathrm{p}=0.86)$ and block $(\mathrm{p}=0.44)$ had no significant effect on carabid activitydensity (Table 16).

Do carabids respond to broadcast seeding of cover crops?

In 2016 and 2017, carabid activity-density did not significantly differ between cover crop species and the control plot after broadcast seeding (Figure 9, Figure 10). 
Figure 9: Carabid activity-density from pitfall traps on June 29 (during seeding) and July 2 (after seedling emergence) in 2016; bold line represents the median value, boxes encompass $25^{\text {th }}$ to $75^{\text {th }}$ percentile, and vertical lines extend to the minimum and maximum values

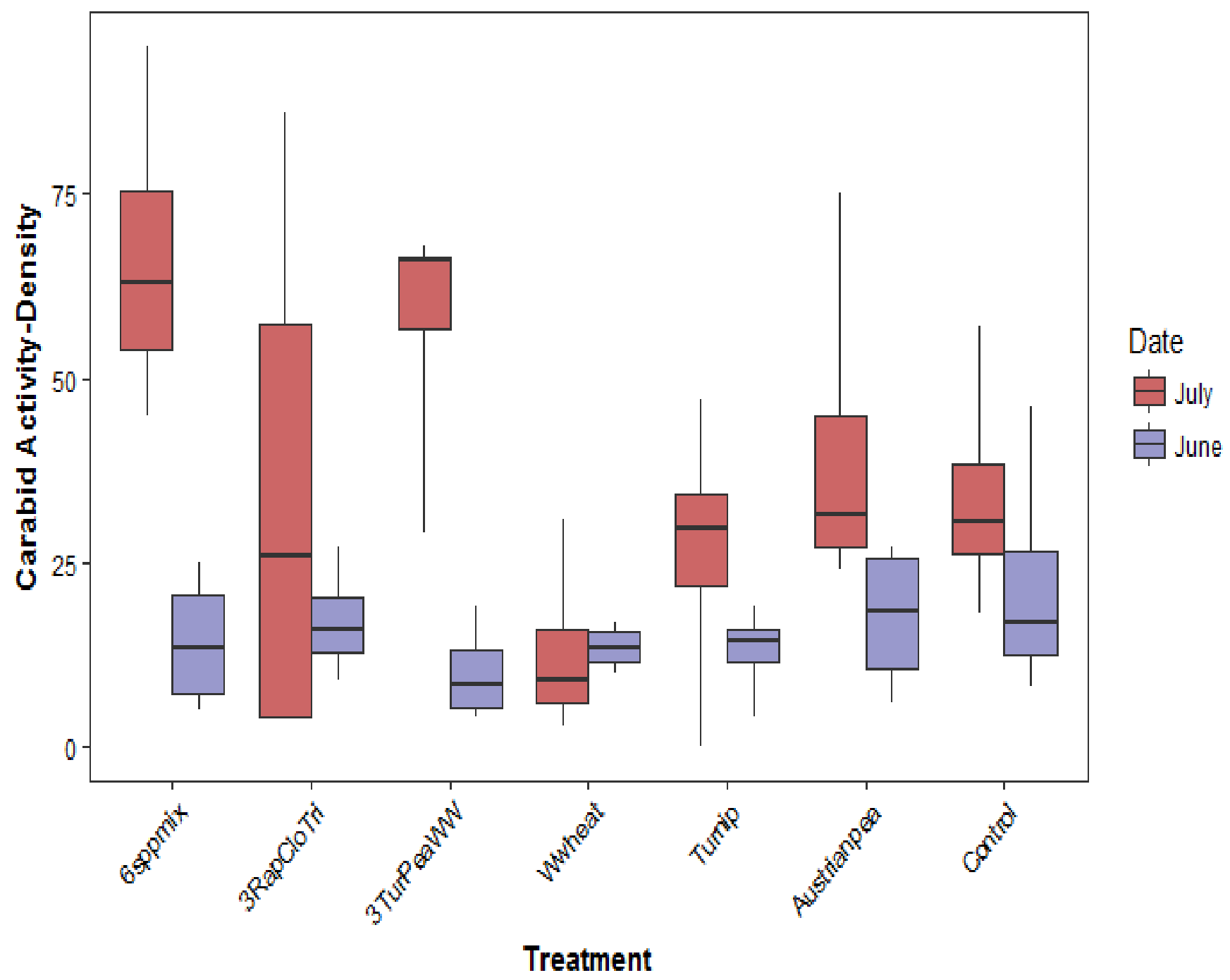


Figure 10: Carabid activity-density from pitfall traps July 7, August 2, and August 24 in 2017; bold line represents the median value, boxes encompass $25^{\text {th }}$ to $75^{\text {th }}$ percentile, and vertical lines extend to the minimum and maximum values

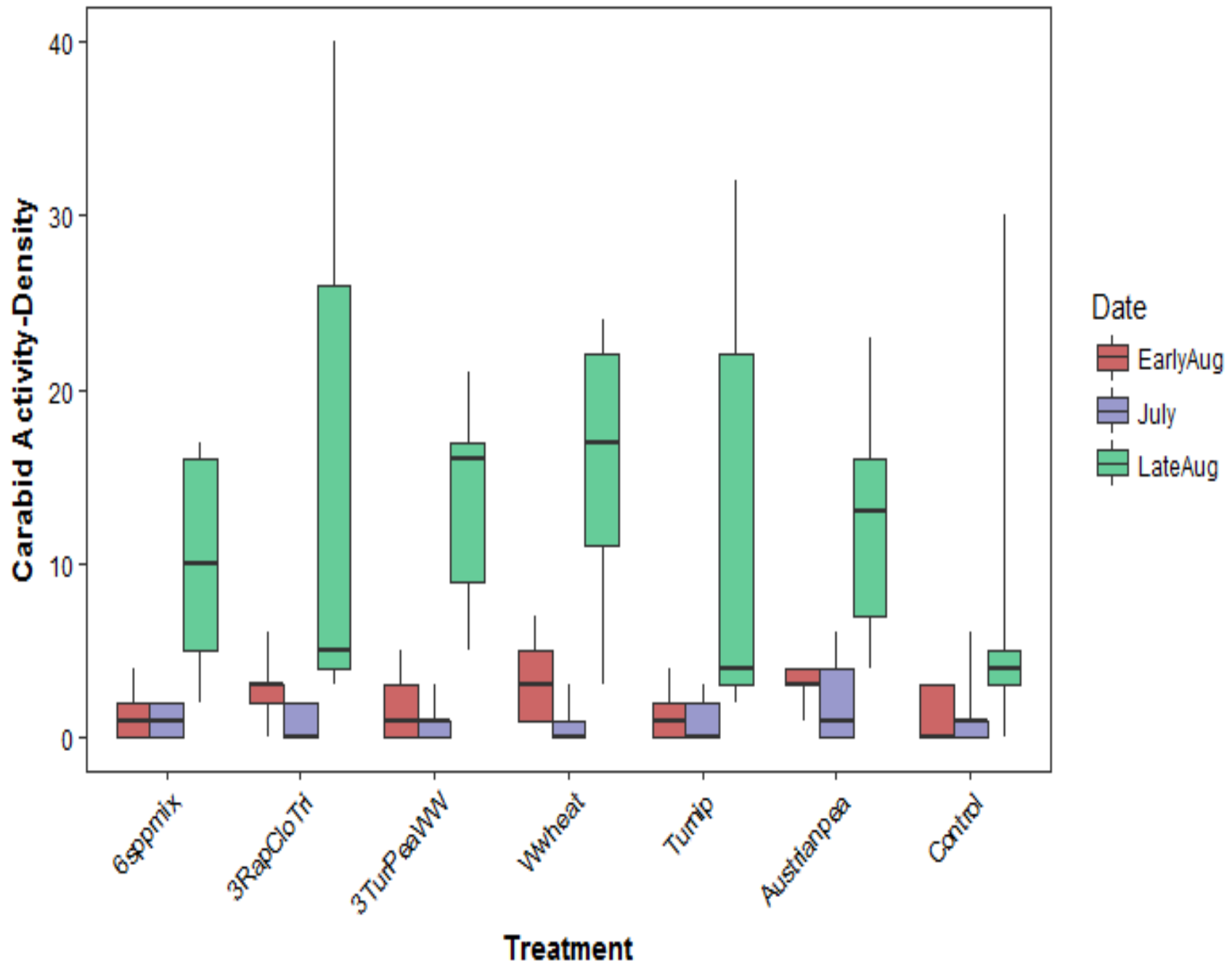

Do carabids respond to vegetative cover provided by cover crops?

In 2016, average vegetative cover was not a significant predictor of carabid activitydensity ( $\mathrm{p}=0.26$ ) (Table 13). The single specie turnip produced the least amount of vegetative cover and the six-species mixture produced the highest average vegetative cover. Cover crop species $(\mathrm{p}<0.001)$ was a significant predictor of average vegetative cover while the variables block ( $\mathrm{p}=0.71$ ) were not significant. In 2016 , vegetative cover was only sampled once in July 
due to field damage from the hailstorm. In 2017, there was a non-significant trend of higher carabid activity-density in plots with more vegetative cover $(\mathrm{p}=0.05)$ (Table 14$)$. The variables cover crop species $(\mathrm{p}<0.001)$, date $(\mathrm{p}<0.001)$ were significant predictors of average vegetative cover. The variable block $(\mathrm{p}=0.38)$ was not a significant predictor of vegetative cover. The single seeded cover crop species turnip produced the least vegetative cover and the three species mixtures rapeseed-clover-triticale and turnip-pea-wheat produced the highest average vegetative cover.

Figure 11: Percent average vegetative cover by cover crop species in 2016; bold line represents the median value, boxes encompass 25 th to 75 th percentile, and vertical lines extend to the minimum and maximum values

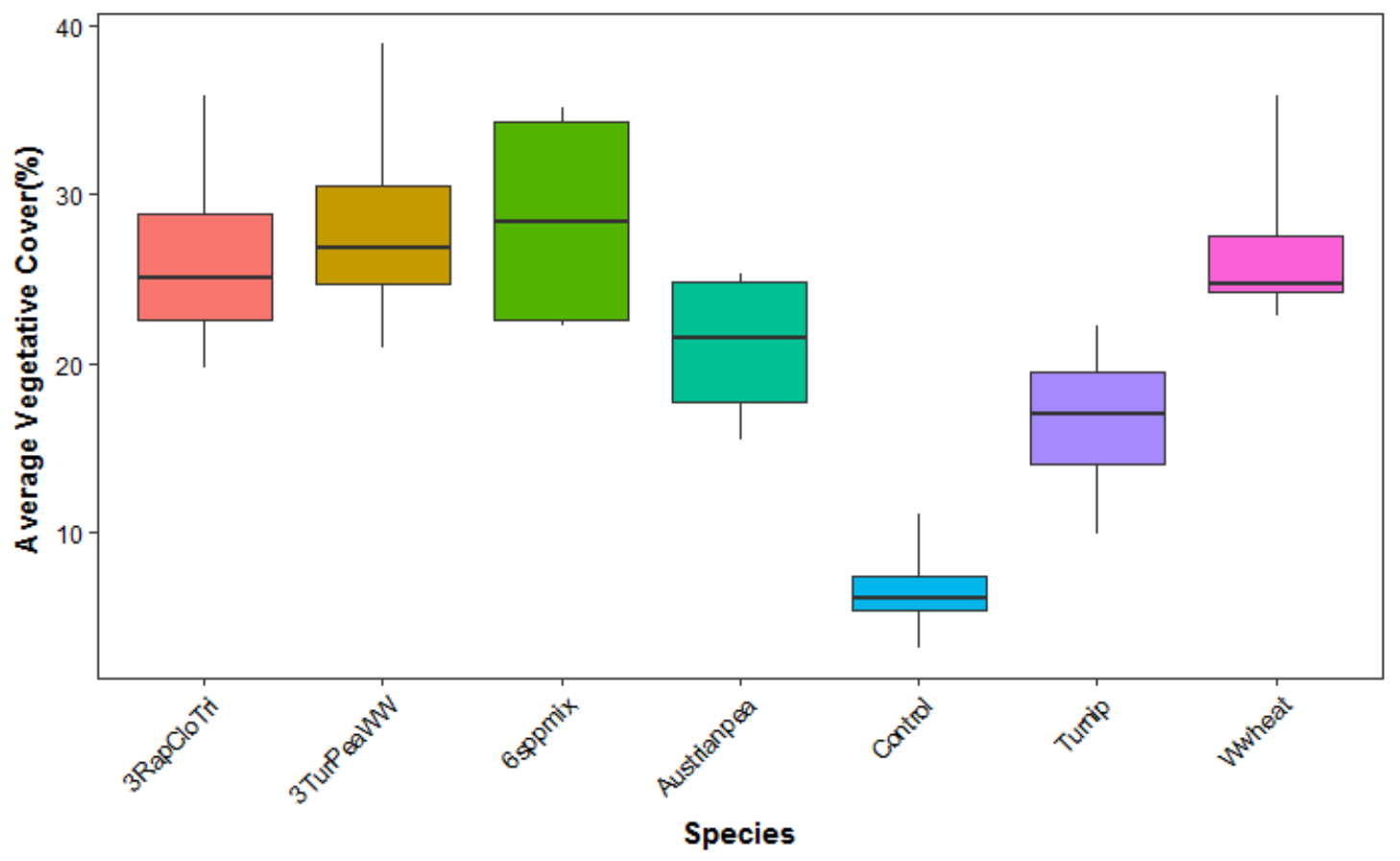


Figure 12: Percent average vegetative cover by cover crop species in 2017; bold line represents the median value, boxes encompass 25 th to 75 th percentile, and vertical lines extend to the minimum and maximum values. Vegetative cover was sampled three times in 2017

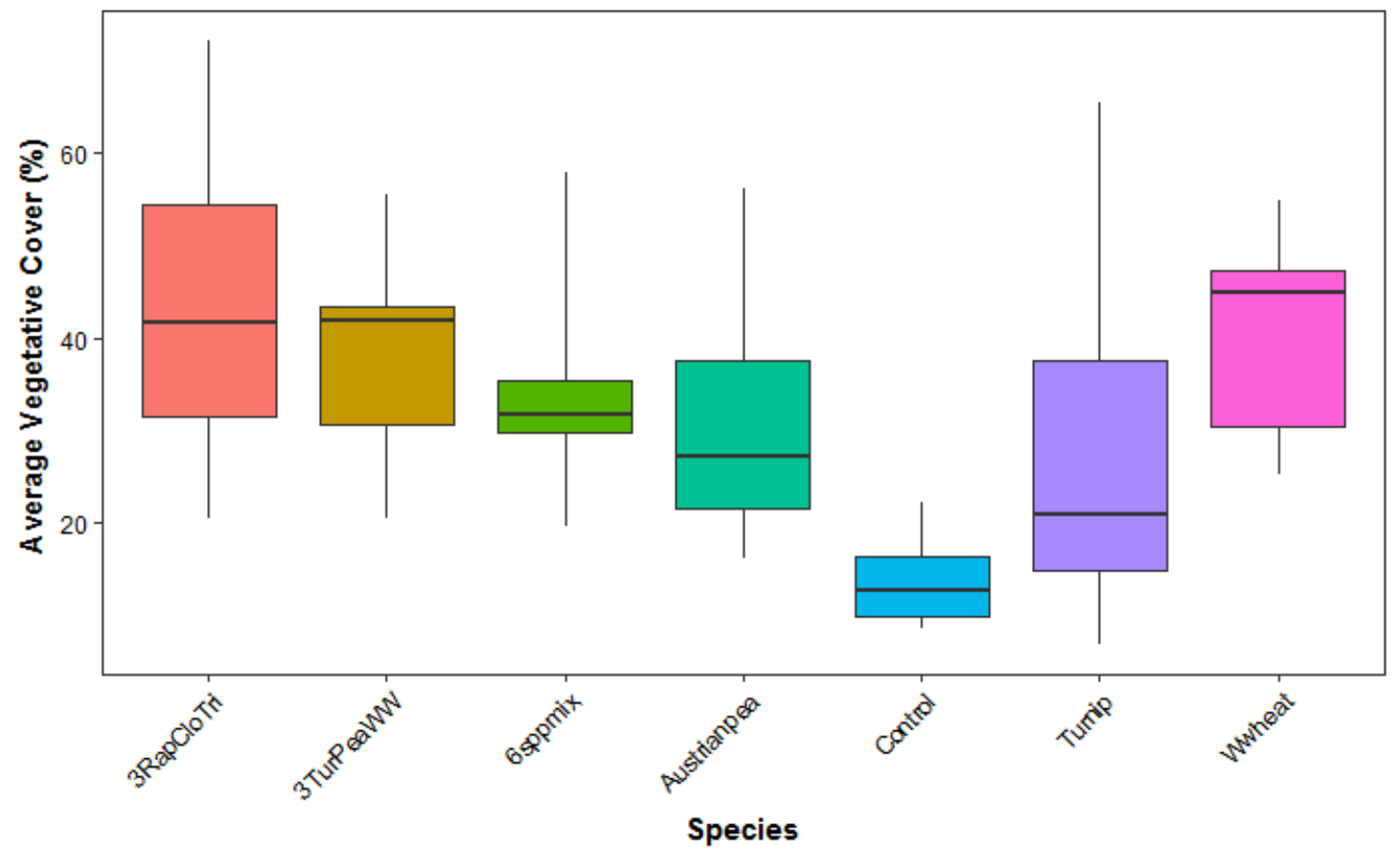




\section{Discussion}

The species of cover crop used for interseeding significantly affected cover crop biomass and levels of seed predation by vertebrate and invertebrate predators. Though carabids were present within the field site, they did not significantly respond to cover crop broadcast seeding events. Carabid activity-density was higher later in the season (July-Aug), but was not significantly influenced by cover crop species or average vegetative cover.

Biomass data revealed that cover crop species was a significant predictor of total biomass and cover crop biomass. However, cover crop species was not a good indicator for weed biomass. This result was contrary to some claims about cover crops providing weed control (Clark, 2007). Though cover crops have been shown to suppress weeds in some scenarios (Upadhyaya \& Blackshaw, 2007), the type of weed species present in the system and the time of weed seedling emergence is a significant aspect associated with proper weed management. There is also risk associated with planting cover crops. For instance, cover crops may have minimal to negative effects on weed control. Compared to farmers, scientists place a higher emphasis on potential risks (Jabbour et al., 2013). The three-species mixture with turnip-peawheat produced the most cover crop biomass. Within the single species treatments, turnip produced the most cover crop biomass. Most of the biomass within these mixtures was attributed to the presence of turnip. Higher diversity within mixtures did not produce more cover crop biomass. Though the 3 -species mixture with turnip-pea-wheat produced the most crop biomass, the three species mixture with rapeseed-clover-and triticale produced less crop 
biomass than all three single seeded species. Furthermore, the six-species mixtures produced less biomass than the three-species turnip-pea-wheat mixture.

My experiment focused on the effect of functional diversity on cover crop yield. However, there are other variables that influence cover crop biomass production, such as planting date. A study in Wyoming by (Meeks, 2016) explored the effects of planting date on forage crop biomass production in standing corn and found that later planting dates resulted in reduced forage biomass compared to earlier planting dates. Similarly, another study found that interseeding cover crops later at the V4-V6 stage of corn growth had higher cover crop biomass production that cover crops that were interseeded at the V10-V12 corn growth stage (Belfry \& Van Eerd, 2016). In my experiment, cover crops were interseeded when corn was at the V6 stage of growth. Although I did not examine this phenomenon, planting date may be a significant predictor for cover crop biomass production, and may impact the productivity of different mixtures or component species.

For the seed assays, there was a trend in both years of higher seed removal in open treatments over exclosure treatments. Vertebrate access to seed assays contributed to higher seed removal than invertebrate access alone. However, the low level of seed predation by invertebrates might be explained by differences in invertebrate community structure throughout the season. In 2016, I observed a higher proportion of granivorous carabids in the later season compared to the earlier season. Because there was seed removal in control treatments, we can assume that seed loss during placement and removal of seed assays in the field also contributed to seed removal rates. In 2017, seed loss on control assays is high for the single species turnip, and the mixtures 3TurCloWW and 6sppmix. Conversely, pea and 
wheat had low rates of control plate seed loss for both years. Seed loss due to water and wind may be greater for smaller seeded species than larger seeded species.

Insects provide many economically valuable services to agroecosystems, including pollination, pest control, and weed suppression (Losey \& Vaughan, 2006). Similarly, vertebrates can help suppress of arthropod pests in agronomic systems (Borkhataria, Collazo, \& Groom, 2006). The presence of vertebrates and invertebrates can also contribute to ecosystem dis-services, such as crop seed loss in agroecosystems (Schackermann, Mandelik, Weiss, Wehrden, \& Klein, 2015). Diversity of granivores differ among systems and regions, which may explain the lack of literature contrasting the roles of vertebrate and invertebrate seed predators within agroecosystems. Surveys of vertebrates though mammal trapping, bird surveys, and game cameras would be useful to determine the composition of vertebrates within my experiment. Weed seed predation research at SAREC that included cameras in the field reported mice and rabbits as likely seed predators (Sbatella, 2006). Collaboration with the University of Wyoming Museum of Vertebrates would also allow me to analyze the stomach contents of vertebrate specimens from Goshen County and determine which vertebrates in the system predate on seeds.

Carabids did not respond differently to control plots compared to other treatment plots during seeding. This suggests that carabids do not respond to crop seeding events. However, seeding date may play a role in carabid activity-density and potential responses. Since carabids likely respond to temperature and season, a later cover crop seeding date may have coincided with higher activity-density of granivorous carabids and more potential seed loss. Other factors in the field may also affect feeding rates by carabids. For instance, one study 
found that predation rates of weed seeds by the carabid Harpalus pensylvanicus increased when seeds were imbibed, due to the increased release of volatile compounds compared to dry seeds (Law \& Gallagher, 2015). Vegetative cover was also not a significant predictor of carabid abundance for 2016. In 2017, there was a non-significant trend of higher carabid activity in plots with more vegetative cover. This suggests that there may be other variables associated with vegetative cover that is attracting carabids. Since temperature plays a role in seed consumption by granivorous carabids (Saska, Martinkova, \& Honek, 2010), vegetative cover may provide a favorable microclimate for carabids. A study by Diel et. al (2012) found that the vegetative cover provided by weeds in an organically managed wheat field increased carabid activity-density through resource-mediated effects, so vegetative cover may also be providing additional shelter and food resources. A study in central Wisconsin comparing the role of crop habitat (a potato field) and non-crop habitat (perennial habitat) found a positive relationship between ground beetle diversity and rates of seed predation in the non-crop habitats, giving evidence that increased plant functional diversity within non-crop habitats contributes to increased ecosystem services (Gaines \& Gratton, 2010). Identifying genus and species composition of collected beetles from pitfall traps would give more insight into how carabid community composition relates to function.

A major goal of this research was to determine if cover crop mixtures produced different ecological effects compared to single species treatments. In terms of cover crop yield, higher diversity within mixtures was not related to greater biomass production. The three-species mixture with turnip-pea-wheat produced the most biomass, but the three-species mixture with rapeseed-clover-triticale produced the least biomass of all mixture and single species 
treatments. For seed predation, results differed by year. In 2016, the three-species mixture with rapeseed-clover-triticale had highest predation in open treatments (vertebrate/invertebrate accessible), and the six-species mixture had highest seed removal rate for exclosure treatments (invertebrate only). In 2017, predation was highest for turnip in open treatments (vertebrate/invertebrate accessible) and the three species mixture with turnipclover-wheat for exclosure treatments (invertebrates only). Though invertebrates had higher predation on seed assays with seed mixtures, higher diversity did not directly provide greater seed predation. The results were also mixed for cover crop diversity influencing carabid activity-density. There was a non-significant trend of higher carabid activity-density by cover crop species in 2016, but this trend did not occur in the following year. For a producer within a semi-arid climate seeking to maximize forage biomass production, I would recommend interseeding a three-species mixture that incorporates turnip, or interseeding turnip as a single species cover crop. However, since turnip had high rates of seed removal, I would recommend seeding turnip in a slightly higher rate to adjust for seed loss. Further analysis on species composition of carabids would be necessary to determine if mixtures or single species treatments are better for carabid abundance in terms of seed removal by the carabid community present in corn. 
CHAPTER TWO: SEED PREDATION RATES OF HARPALUS 


\section{Introduction}

Ground beetles (Coleoptera: Carabidae) are highly abundant within agroecosystems (Holland, 2002). Carabids as a family are polyphagous; they have been documented as generalist predators of insect pests and as seed predators (Jorgensen \& Toft, 1997; Kulkarni, Dosdall, \& Willenborg, 2015). Therefore, there are strong indicators that carabids may be important management tools for pest and weed suppression. There are three genera of carabids recognized to be predominately granivorous: Harpalus, Amara, and Zabrus (Johnson \& Cameron, 1969). The carabid species you will find in an agricultural field at a particular time is dependent upon environmental conditions. Certain species of carabids are only found during a specific time of season due to temperature constraints on feeding behavior and fecundity (Honek et al., 2006). Though there are fluctuations in activity density between carabid species, populations within ecosystems are usually consistent (Holland, 2002).

Carabids can have a substantial effect on weed seeds present in the seed bank. This is in part because seeds are an optimum diet for larval development and adult fecundity. There have been several studies investigating feeding specialization in carabid beetles. One study showed that seeds were a more valuable food source than insect-only diets for adult and larval development of Harpalus rufipes (Jorgensen \& Toft, 1997). A study on the fecundity of three species of carabids in the genus Amara showed that females lay significantly more eggs with seed-only diets and mixed diets compared to insect-only diets (Saska, 2008). Fecundity and 
male gonad maturation in Anisodactylus punctatipennis were higher in individuals fed diets containing seeds compared to individuals fed insect-only diets (Sasakawa, 2009).

Past studies also demonstrate carabid preference for various species of weed seeds (Johnson \& Cameron, 1969; Petit et al., 2014). However, there is a general lack of studies exploring carabid preference for crop seeds. If carabids share similar preference for seeds, crop seeds may be especially vulnerable to predation. Covered or buried seeds are less likely to be lost to seed predators (Westerman, Dixon, \& Liebman, 2009), and crop seeds are buried in most instances. If carabids feed on crop seeds, however, this can be particularly problematic in applications where seed is broadcast on the surface, which is one common way of seeding cover crops. In this study, I investigated the seed preference of an unidentified carabid species in the genus Harpalus. The objectives of this study were to: 1.) determine if Harpalus sp. will feed on cover crop seeds and 2.) determine if Harpalus sp. will feed on crop seed over weed seeds 


\section{Materials and Methods}

\subsection{Carabid Species}

I conducted a seed preference experiment within a laboratory setting. Beetles were captured using pitfall traps in the field on September 16, 2016 at the James C. Hageman Sustainable Agriculture Research and Extension Center (SAREC) in Lingle, WY (45.9156" $\left.\mathrm{N}, 24.8784^{\prime \prime} \mathrm{W}\right)$. Upon capture, beetles were transferred to an incubator at $5^{\circ} \mathrm{C}$ for 5 days in order to standardize levels of hunger and prevent cannibalism (Honek, Martinkova, Saska, \& Pekar, 2007; Petit et al., 2014). All beetles used for experimentation were the same species within the genus Harpalus, a carabid genus that is primarily granivorous and I found to be abundant at the field site in 2016 (Figure 11).

Figure 13: Harpalus beetle used for the experiment

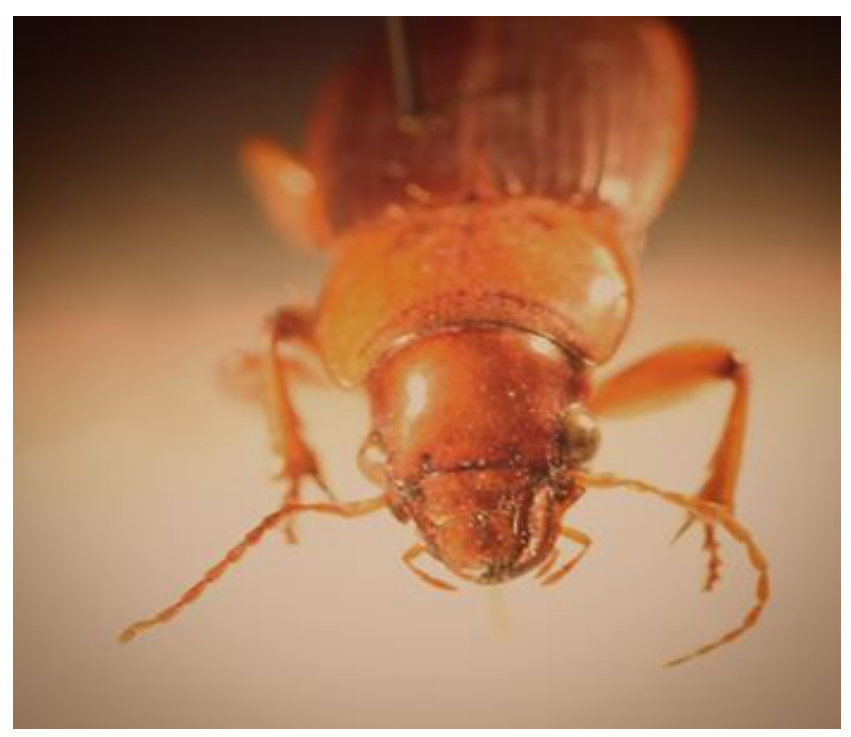




\subsection{Seed species}

I used six species for this experiment: three weed species-kochia (Kochia scoparia), redroot pigweed (Amaranthus retroflexus), and common lambsquarters (Chenopodium album)-and three crop species --red clover (Trifolium pretense), turnip (Brassica rapa), and rapeseed (Brassica napus). Kochia, redroot pigweed, and common lambsquarters are common weeds found in crop fields in Wyoming and were especially abundant within the field site where the beetles were collected. Clover, turnip, and rapeseed are commonly used species of cover crops that could possibly be broadcast seeded and vulnerable to predation. Because the literature suggests smaller seeded species are more vulnerable to carabid feeding (Honek et al., 2007), the cover crop species chosen were small relative to the size of Harpalus. All seed species were weighed to determine if seed mass influenced predation rates (Table 5).

Table 5: weight in grams of 100 seeds for each seed species

\begin{tabular}{lc}
\hline Seed species & Mass $(\mathrm{g}) / 100$ seeds \\
\hline Lambsquarters & 0.05 \\
Pigweed & 0.06 \\
Kochia & 0.1 \\
Clover & 0.2 \\
Turnip & 0.2 \\
Rapeseed & 0.4 \\
\hline
\end{tabular}

\subsection{No-Choice Experiment}

To assess seed preference of Harpalus, a no-choice experiment was conducted. For the no-choice experiment, a single adult beetle was placed in a "beetle cage" filled with 1.5 $\mathrm{cm}$ of field soil with a seed dish and a piece of moist cotton to serve as a water source. The 
container used for experimentation measured $10 \mathrm{x} 10 \mathrm{~cm}$, with a mesh top to allow for ventilation (Figure 12).

Seed dishes measured $5 \mathrm{~cm}$ in diameter and $1 \mathrm{~cm}$ deep, and were positioned to be level with the soil. Seed dishes were filled with white modeling clay and seeds were pressed into the plate lightly so they were both secure on the plate, and could be removed easily (Honek et al., 2007). Based on preliminary observations, beetles do not consume modeling clay. Seed preference trials occurred from September 20-25, 2016. Each seed dish had 50 seeds of a single species evenly distributed on the plate. The experiment consisted of three replicates per seed species. I measured seed consumption every 24 hours, and replaced seed dishes daily to ensure an abundant food supply. I recorded partially consumed seeds as eaten and checked the surrounding soil daily for any displaced seeds 
Figure 14: Example set up of a beetle cage for the no-choice seed preference experiment: A.) Seed dish with 50 seeds B.) Moist cotton C.) Soil collected from field site

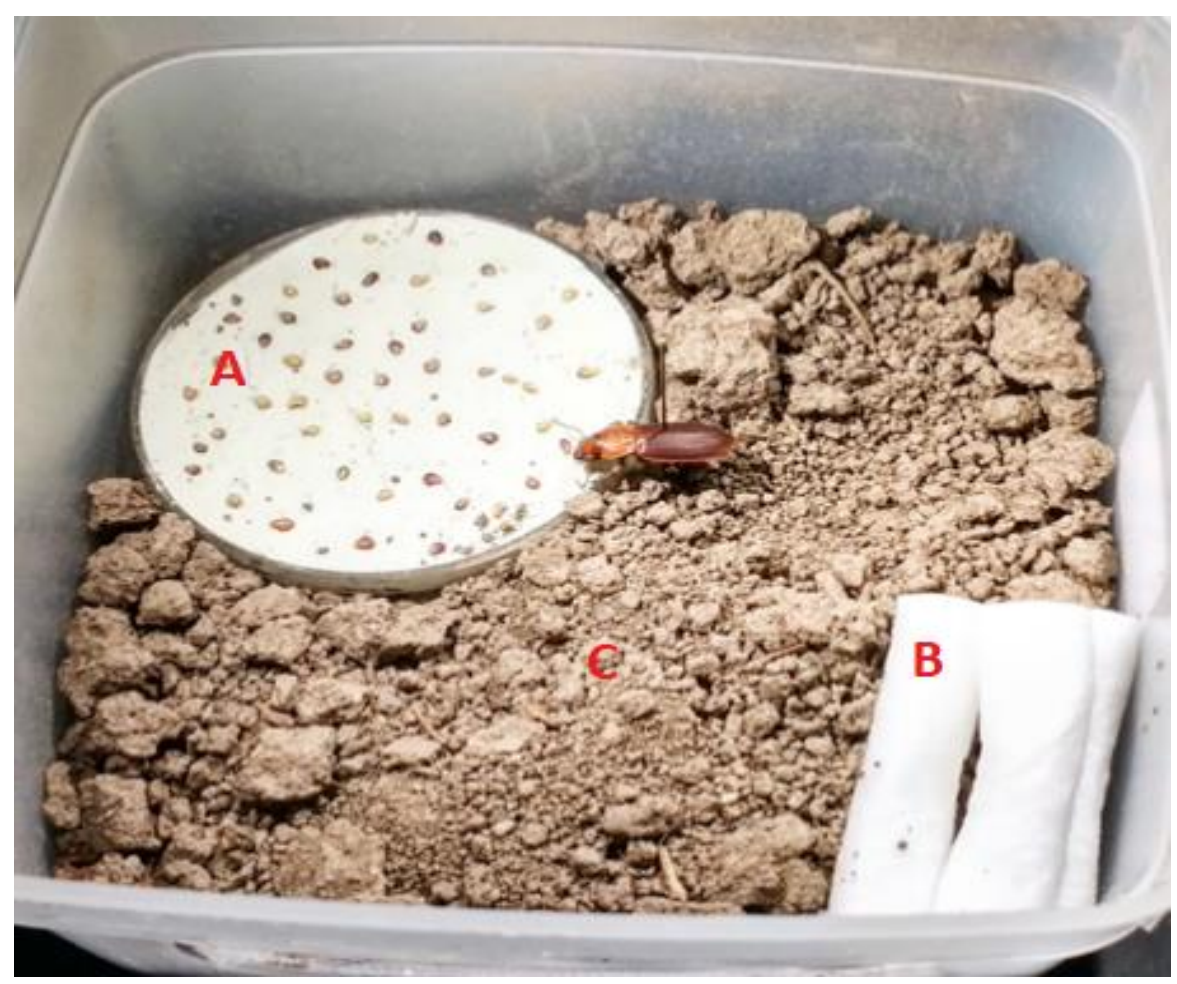


Daily seed consumption was recorded as a percentage (number of seeds eaten/50 seeds per seed dish) and was averaged for the 5 days of the experiment. Model fit was evaluated in $\mathrm{R}$ studio (R Core Team, 2016) using the package agricolae (de Mendiburu, 2016). An ANOVA was used to test if carabid feeding varied among the seed species. I interpreted the analysis to answer the following research questions:

- Does Harpalus sp. predate on cover crop seeds?

- Does Harpalus sp. prefer weed seeds or crop seeds? 


\section{Results}

Does Harpalus sp. predate on crop seeds?

Given no choice, beetles consumed crop seeds (Figure 13). Of the three crop seeds used for the experiment, beetles consumed the highest percent of clover seeds (Table 7). Beetles consumed rapeseed and turnip, both species within the family Brassicaceae, at the lowest rate.

Figure 15: Percent consumption (out of 50 seeds) of weed and cover crop seeds measured over five consecutive days; bold line represents the median value, boxes encompass $25^{\text {th }}$ to $75^{\text {th }}$ percentile, and vertical lines extend to the minimum and maximum values

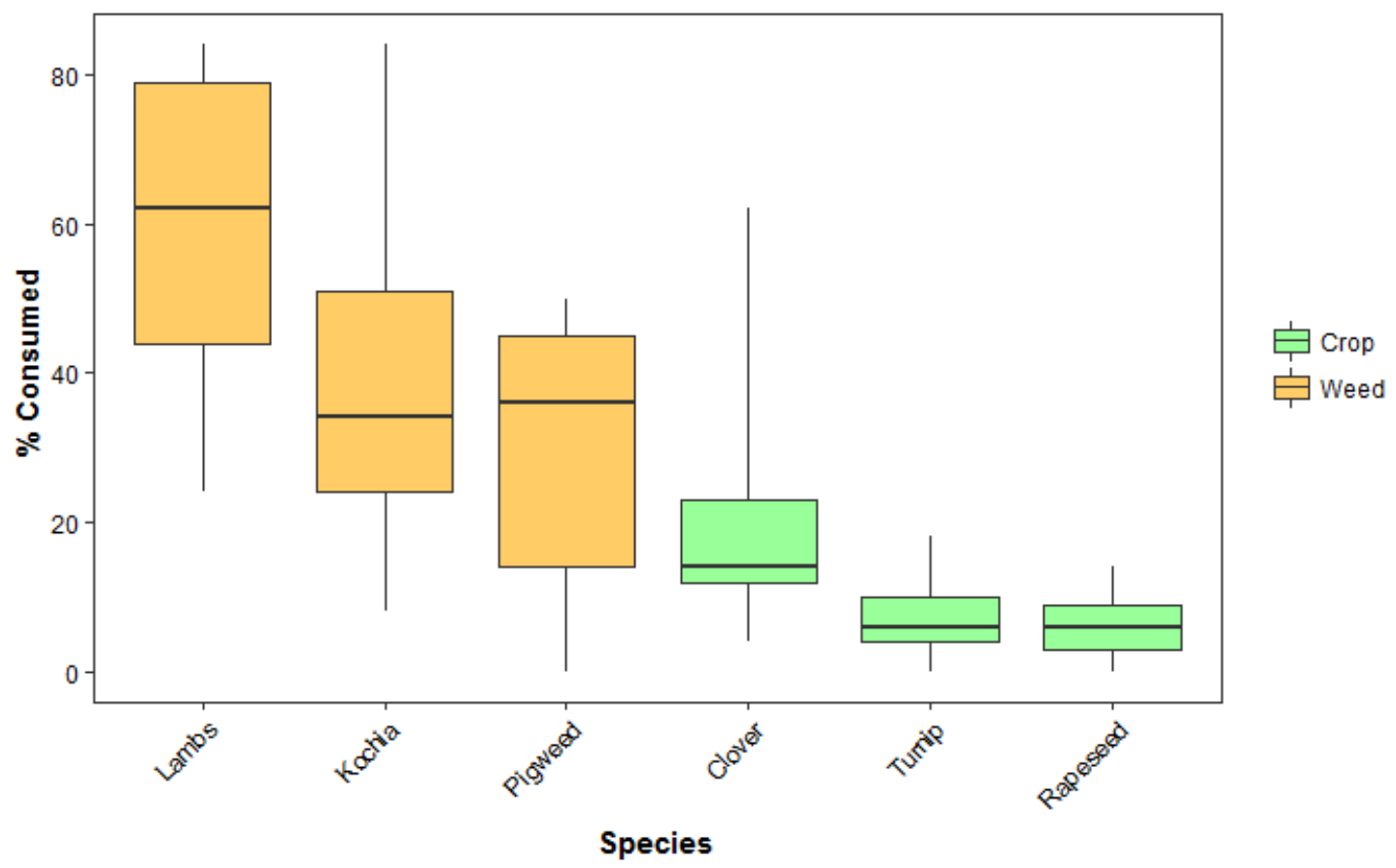


Does Harpalus sp. prefer weed seeds or crop seed?

Given the selected species in no-choice trials, beetles consumed higher proportions of weed seed species over crop seed species. Weed seed consumption ranged from 35 to $64 \%$ across the three species, whereas crop seed consumption ranged from 8-17\%. Overall, beetles consumed lambsquarter at the highest rate and rapeseed at the lowest rate $(\mathrm{p}=0.03)$.

Table 6: Average consumption and standard deviation (SD) for each seed species. Average consumption is reported as percent consumed out of 50 seeds

\begin{tabular}{lcc}
\hline Species & Avg. Consumption (\%) & SD \\
\hline Lambsquarters & 64 & 0.19 \\
Kochia & 55.33 & 0.28 \\
Pigweed & 34.66 & 0.17 \\
Clover & 17.33 & 0.07 \\
Turnip & 10 & 0.04 \\
Rapeseed & 8.66 & 0.05 \\
\hline
\end{tabular}




\section{Discussion}

Among the six seed species used, beetles ate crop seeds at a lower rate compared to weed species. Nevertheless, these results indicate that crop seed predation should be taken into consideration. Even a low removal rate of cover crop seeds could affect distribution and establishment success of cover crops or lead to patchy establishment depending on the density of carabids and other seed predators within the field site. On the other hand, removal rate of crop seeds may be less important depending on crop seeding date. Because fall seeding of cover crops is common in some systems, it may be possible that weed seed rain and cover crop seeding would co-occur. The presence of weed seeds may divert predation pressure from crop seeds. Changing seeding strategy, planting date, or increasing cover crop seeding rate may be a good preventative measure against seed predation by carabids.

There have been several studies investigating other factors associated with carabid seed preference. Physiological factors, such as carabid morphology, taxonomic constraints, and seed size influences have been shown to influence seed preference (Honek, Martinkova, Saska, \& Pekar, 2007). In this experiment, there was a general trend of higher consumption rates for seeds with a lower mass (Table 5). Other variables present within agroecosystems may influence seed preference as well. One study showed that Harpalus rufipes had higher rates of predation on weed seeds present on the soil surface and in habitats with less soil disturbance (Harrison \& Gallandt, 2012). Rate of predation can also be affected by environmental factors. In another recent study, increased temperature was correlated with 
increased rate of seed predation in the carabid species Pseudoophonus rufipes and Harpalus affini (Saska et al., 2010).

A more comprehensive study will likely give more insight into carabid seed preference. In my study, Harpalus $s p$. preferred weed seed to crop seed species. However, this data is specific to the species used in the experiment. Further experimentation, such as a choice experiment, would also be necessary for supplemental support of the data. A choice experiment is similar in design to the no-choice experiment, except a single adult beetle would be able to choose from all six species of seeds. I attempted to conduct a choice experiment in Fall 2017, but due to beetle mortality and difficulty finding the same species of beetle, the study could not be performed. Furthermore, since I collected beetles from the field with an unknown feeding history and exposed them to seeds they may not be familiar with, it may be interesting to test for these effects. 


\section{Conclusion}

Cover crop species was a significant predictor of total biomass and cover crop biomass production, but did not affect weed biomass. Seed predation rates were significantly influenced by seed composition and species. Cover crop seeding events did not affect carabid activity-density. Cover crop species also did not influence carabid activity-density; however, there was a non-significant trend of higher carabid activity-density by cover crop species composition in 2016, but not in 2017. Carabid activity-density significantly increased as the season progressed. Average vegetative cover did not affect carabid-activity density, which suggests there are other factors associated with vegetative cover that are influencing carabid activity.

In a no-choice experiment, Harpalus consumed crops seeds. However, weed seeds had a higher rate of consumption than crop seeds. With further experimentation and analysis, my results can inform farmer decision for choosing the most effective seeding method and crop types for cover crop establishment. 


\section{References}

Belfry, K. D., \& Van Eerd, L. L. (2016). Establishment and Impact of Cover Crops Intersown into Corn. Crop Science, 56, 1-12. http://doi.org/10.2135/cropsci2015.06.0351

Bigelow, D. P., \& Borchers, A. (2017). Major Uses of Land in the United States , 2012. U.S. Department of Agriculture, Economic Research Service, (178).

Birthisel, S. K., Gallandt, E. R., Jabbour, R., \& Drummond, F. A. (2015). Habitat and time are more important predictors of weed seed predation than space in a Maine USA mixed vegetable agroecosystem. Weed Science, 63(4), 916-927. http://doi.org/10.1614/WS-D-1500057.1

Blubaugh, C. K., Hagler, J. R., Machtley, S. A., \& Kaplan, I. (2016). Cover crops increase foraging activity of omnivorous predators in seed patches and facilitate weed biological control. Agriculture, Ecosystems and Environment, 231, 264-270. http://doi.org/10.1016/j.agee.2016.06.045

Blubaugh, C. K., \& Kaplan, I. (2016). Invertebrate Seed Predators Reduce Weed Emergence Following Seed Rain. Weed Science, 64(1), 80-86. http://doi.org/10.1614/WS-D-15-00111.1

Booth, T., Cox, S. E., \& Berryman, R. D. (2006). Point sampling digital imagery with 'samplepoint.' Environmental Monitoring and Assessment, 123, 97-108. http://doi.org/10.1007/s10661-005-9164-7

Brooks, D. R., Storkey, J., Clark, S. J., Firbank, L. G., Petit, S., \& Woiwod, I. P. (2012). Trophic links between functional groups of arable plants and beetles are stable at a national scale. Journal of Animal Ecology, 81, 4-13. http://doi.org/10.1111/j.1365-2656.2011.01897.x

Buchmann, N. (2006). Quantifying the evidence for biodiversity effects on ecosystem functioning and services. Ecology Letters, 9, 1146-1156. http://doi.org/10.1111/j.14610248.2006.00963.x 
Carmona, D. M., \& Landis, D. A. (1999). Influence of Refuge Habitats and Cover Crops on Seasonal Activity- Density of Ground Beetles (Coleoptera : Carabidae) in Field Crops. Environmental Entomology, 28(6), 1145-1153.

http://doi.org/https://doi.org/10.1093/ee/28.6.1145

Diehl, E., Wolters, V., \& Birkhofer, K. (2012). Arable weeds in organically managed wheat fields foster carabid beetles by resource- and structure-mediated effects. Arthropod-Plant Interactions, 6, 75-82. http://doi.org/10.1007/s11829-011-9153-4

Finney, D. M., \& Kaye, J. P. (2016). Functional diversity in cover crop polycultures increases multifunctionality of an agricultural system. Journal of Applied Ecology, 54(2), 509-517. http://doi.org/10.1111/1365-2664.12765

Gaines, H. R., \& Gratton, C. (2010). Seed predation increases with ground beetle diversity in a Wisconsin (USA) potato agroecosystem. Agriculture, Ecosystems and Environment, 137(3-4), 329-336. http://doi.org/10.1016/j.agee.2010.03.003

Harrison, S., \& Gallandt, E. R. (2012). Behavioural Studies of Harpalus rufipes De Geer: an Important Weed Seed Predator in Northeastern US Agroecosystems. International Journal of Ecology, 1-6. http://doi.org/10.1155/2012/846546

Hively, W. D., \& Cox, W. J. (2001). Interseeding Cover Crops into Soybean and Subsequent Corn Yields. Agronomy Journal, 93, 308-313. http://doi.org/doi:10.2134/agronj2001.932308x

Holland, J. (2002). The Agroecology of Carabid Beetles. (J. Holland, Ed.). Andover, UK: Intercept Limited.

Honek, A., Martinkova, Z., Saska, P., \& Pekar, S. (2007). Size and taxonomic constraints determine the seed preferences of Carabidae (Coleoptera). Basic and Applied Ecology, 8(4), 343-353. http://doi.org/10.1016/j.baae.2006.07.002

Honek, A., Saska, P., \& Martinkova, Z. (2006). Seasonal variation in seed predation by adult 
carabid beetles. Entomologia Experimentalis et Applicata, 118, 157-162.

http://doi.org/doi:10.1111/j.1570-7458.2006.00376.x

Jabbour, R., Zwickle, S., Gallandt, E. R., Mcphee, K. E., Wilson, R. S., \& Doohan, D. (2013).

Mental models of organic weed management: Comparison of New England US farmer and expert models. Renewbable Agriculture and Food Systems, 1-15. http://doi.org/10.1017/S1742170513000185

Johnson, N. E., \& Cameron, R. S. (1969). Phytophagous ground beetles. Annals of the Entomological Society of America, 62(4), 909-914. Retrieved from http://www.ingentaconnect.com/content/esa/aesa/1969/00000062/00000004/art00046

Jorgensen, H. B., \& Toft, S. (1997). Role of granivory and insectivory in the life cycle of the carabid beetle Amara similata. Ecological Entomology, 22(1), 7-15. http://doi.org/10.1046/j.1365-2311.1997.00045.x

Kaye, J. P., \& Quemada, M. (2017). Using cover crops to mitigate and adapt to climate change . A review. Agronomy for Sustainable Development, 37(4). http://doi.org/10.1007/s13593-0160410-x

Kulkarni, S. S., Dosdall, L. M., \& Willenborg, C. J. (2015). The Role of Ground Beetles (Coleoptera: Carabidae) in Weed Seed Consumption: A Review. Weed Science, 63(02), 355376. http:/ /doi.org/10.1614/WS-D-14-00067.1

Law, J. J., \& Gallagher, R. S. (2015). The role of imbibition on seed selection by Harpalus pensylvanicus. Applied Soil Ecology, 87, 118-124. http://doi.org/10.1016/j.apsoil.2014.11.015

Lester, D. G., \& Morrill, W. L. (1988). Activity-Density of Ground Beetles (Coleoptera: Carabidae) in Alfalfa and Sanfoin. Journal of Agriculture and Urban Entomology, 6(2), 71-76.

Lu, Y.-C., Watkins, K. B., Teasdale, J. R., \& Abdul-Baki, A. A. (2000). Cover Crops in Sustainable Food Production. Food Rev. Int, 16(2), 121-157. http://doi.org/10.1081/FRI-100100285

Lundgren, J. G., Shaw, J. T., Zaborski, E. R., \& Eastman, C. E. (2006). The influence of organic 
transition systems on beneficial ground-dwelling arthropods and predation of insects and weed seeds. Renewbable Agriculture and Food Systems, 21(4), 227-237. http://doi.org/10.1079/RAF2006152

Meeks, J. (2016). Seeding Date and Herbicide Effects on interseeded winter forage crops. University of Wyoming.

Petit, S., Boursault, A., \& Bohan, D. A. (2014). Weed seed choice by carabid beetles (Coleoptera: Carabidae): Linking field measurements with laboratory diet assessments. European Journal of Entomology, 111(5), 615-620. http://doi.org/10.14411/eje.2014.086

Roth, G., \& Curran, W. S. (2015). Improving the Success of Interseeding Cover Crops in Corn. Retrieved from http://www.kingsagriseeds.com/wp-content/uploads/2014/12/improving-thesuccess-of-interseeding-cover-crops-in-corn-1.pdf

Sasakawa, K. (2009). Diet affects male gonad maturation, female fecundity, and larval development in the granivorous ground beetle Anisodactylus punctatipennis. Ecological Entomology, 34, 406-411. http://doi.org/10.1111/j.1365-2311.2009.01092.x

Saska, P. (2008). Effect of diet on the fecundity of three carabid beetles. Physiological Entomology, 33(3), 188-192. http://doi.org/10.1111/j.1365-3032.2008.00618.x

Saska, P., Martinkova, Z., \& Honek, A. (2010). Temperature and Rate of Seed Consumption by Ground Beetles (Carabidae). Biological Control, 52(2), 91-95. http://doi.org/10.1016/j.biocontrol.2009.07.016

Sbatella, G. M. (2006). Jointed Goatgrass Viability Loss Under Different Environments. University of Wyoming.

Smith, R. G., Atwood, L. W., \& Warren, N. D. (2014). Increased Productivity of a Cover Crop Mixture Is Not Associated with Enhanced Agroecosystem Services. PLoS ONE, 9(5). http://doi.org/10.1371/journal.pone.0097351

Snapp, S. S., Swinton, S. M., Labarta, R., Mutch, D., Black, J. R., \& Leep, R. (2005). Evaluating 
Cover Crops for Benefits, Costs and Performance within Cropping System Niches of Crop and impact of foregoing a cash crop, some farmers express Michigan and New York producers are experimenting. Agronomy Journal, 97, 322-332.

http://doi.org/10.2134/agronj2005.0322

USDA. (2010). Aerial Seeding of Cover Crops. Des Moines, Iowa. Retrieved from https://prod.nrcs.usda.gov/Internet/FSE_DOCUMENTS/stelprdb1167304.pdf

Westerman, P. R., Dixon, P. M., \& Liebman, M. (2009). Burial rates of surrogate seeds in arable fields. Weed Research, 42, 142-152. http://doi.org/10.1111/j.1365-3180.2008.00684.x

Wilson, M. L., Allan, D. L., \& Baker, J. M. (2014). Aerially Seeding Cover Crops in the Northern US Corn Belt: Limitations, Future Research Needs, and Alternative Practices. Journal of Soil and Water Conservation, 69(3), 67-72.

Wilson, M. L., Baker, J. M., \& Allan, D. L. (2013). Factors Affecting Successful Establishment of Aerially Seeded Winter Rye. Agronomy Journal, 105(6).

http://doi.org/10.2134/agronj2013.0133 


\section{Appendix}

Table 7: Summary statistics for log total biomass

\begin{tabular}{lccccc}
\hline & Df & Sun Sq & Mean Sq & F-value & $\operatorname{Pr}(>F)$ \\
\hline Species & 6 & 14.07 & 2.35 & 4.33 & 0.00328 \\
Residuals & 28 & 15.17 & 0.54 & & \\
\hline
\end{tabular}

Table 8: Summary statistics for log crop biomass

\begin{tabular}{lccccc}
\hline & Df & Sun Sq & Mean Sq & F-value & $\operatorname{Pr}(>\mathrm{F})$ \\
\hline Species & 6 & 205.9 & 34.33 & 56.21 & $2.50 \mathrm{E}-14$ \\
Residuals & 28 & 17.1 & 0.61 & & \\
\hline
\end{tabular}

Table 9: Summary statistics for log weed biomass

\begin{tabular}{lccccc}
\hline & Df & Sun Sq & Mean Sq & F-value & $\operatorname{Pr}(>\mathrm{F})$ \\
\hline Species & 6 & 23.43 & 3.91 & 0.872 & 0.528 \\
Residuals & 28 & 125.39 & 4.48 & & \\
\hline
\end{tabular}

Table 10: Summary statistics for 2016 seed assay analysis

\begin{tabular}{lccccc}
\hline & Df & Deviance Resid & Df & Resid. Der & PR( $>$ Chi) \\
\hline NULL & & & 87 & 437.31 & \\
Species & 5 & 131.673 & 82 & 305.64 & $<2.2 \mathrm{E}-16$ \\
Treatment & 2 & 29.1 & 80 & 276.54 & $4.78 \mathrm{E}-07$ \\
Block & 4 & 10.323 & 76 & 266.21 & 0.03532 \\
Species:Treatment & 10 & 44.023 & 66 & 222.19 & $3.26 \mathrm{E}-06$ \\
\hline
\end{tabular}

Table 11: Summary statistics for 2017 seed assay analysis. Repetitions increased from four to five in 2017.

\begin{tabular}{lccccc}
\hline & Df & Deviance Resi & Df & Resid. De & PR(>Chi) \\
\hline NULL & & & 70 & 389.27 & \\
Species & 5 & 127.516 & 65 & 261.76 & $<2.2 \mathrm{E}-16$ \\
Treatment & 2 & 55.117 & 63 & 206.64 & $1.08 \mathrm{E}-12$ \\
Block & 3 & 15.757 & 60 & 190.88 & 0.001271 \\
Species:Treatment & 10 & 18.913 & 50 & 171.97 & 0.041376 \\
\hline
\end{tabular}


Table 12: Summary statistics for 2016 average vegetative cover analysis.

\begin{tabular}{lccccc}
\hline & Df & Sum Sq & Mean Sq & F value & $\operatorname{Pr}(>\mathrm{F})$ \\
\hline Species & 6 & 7844.2 & 1307.37 & 2.33 & 0.105 \\
AvgCover & 1 & 761.2 & 761.17 & 1.35 & 0.268 \\
Block & 3 & 104.1 & 34.71 & 0.06 & 0.978 \\
Species:AvgCover & 6 & 4174.3 & 695.72 & 1.24 & 0.365 \\
Residuals & 11 & 6157.1 & 559.74 & & \\
\hline
\end{tabular}

Table 13: Average vegetative cover analysis for 2017. Analysis of Variance Table of type III with Satterthwaite approximation for degrees of freedom.

\begin{tabular}{lcccccc}
\hline & Sum Sq & Mean Sq & NumDF & DenDF & F value & $\operatorname{Pr}(>\mathrm{F})$ \\
\hline Species & 459.79 & 76.63 & 6 & 51 & 1.71 & 0.13664 \\
Date & 1187.49 & 1187.49 & 1 & 51 & 26.56 & $4.18 \mathrm{E}-06$ \\
Block & 210.81 & 52.7 & 4 & 51 & 1.17 & 0.33116 \\
AvgCover & 178.67 & 178.67 & 1 & 51 & 3.99 & 0.05093 \\
Species:AvgCover & 496.34 & 82.72 & 6 & 51 & 1.85 & 0.10775 \\
\hline
\end{tabular}

Table 14: Pitfall summary for 2016. Analysis of Variance Table of type III with Satterthwaite approximation for degrees of freedom

\begin{tabular}{lcccccc}
\hline & Sum Sq & Mean Sq & NumDF & DenDF & F value & $\operatorname{Pr}(>\mathrm{F})$ \\
\hline Species & 3975.3 & 662.5 & 6 & 34.509 & 2.3 & 0.0566 \\
Date & 7873.1 & 7873.1 & 1 & 31.787 & 27.33 & $1.42 \mathrm{E}-05$ \\
Block & 200.4 & 66.8 & 3 & 31.787 & 0.23 & 0.8735 \\
Species:Date & 4447.6 & 741.3 & 6 & 31.787 & 2.57 & 0.03801 \\
\hline
\end{tabular}

Table 15: Pitfall summary for 2017. Analysis of Variance Table of type III with Satterthwaite approximation for degrees of freedom

\begin{tabular}{lcccccc}
\hline & Sum Sq & Mean Sq & NumDF & DenDF & F value & $\operatorname{Pr}(>\mathrm{F})$ \\
\hline Species & 105.96 & 17.66 & 6 & 83 & 0.422 & 0.8623 \\
Date & 2802.34 & 1401.17 & 2 & 83 & 33.495 & $2.16 \mathrm{E}-11$ \\
Block & 24.69 & 24.69 & 1 & 83 & 0.59 & 0.4446 \\
Species:Date & 137.52 & 11.46 & 12 & 83 & 0.274 & 0.9918 \\
\hline
\end{tabular}


